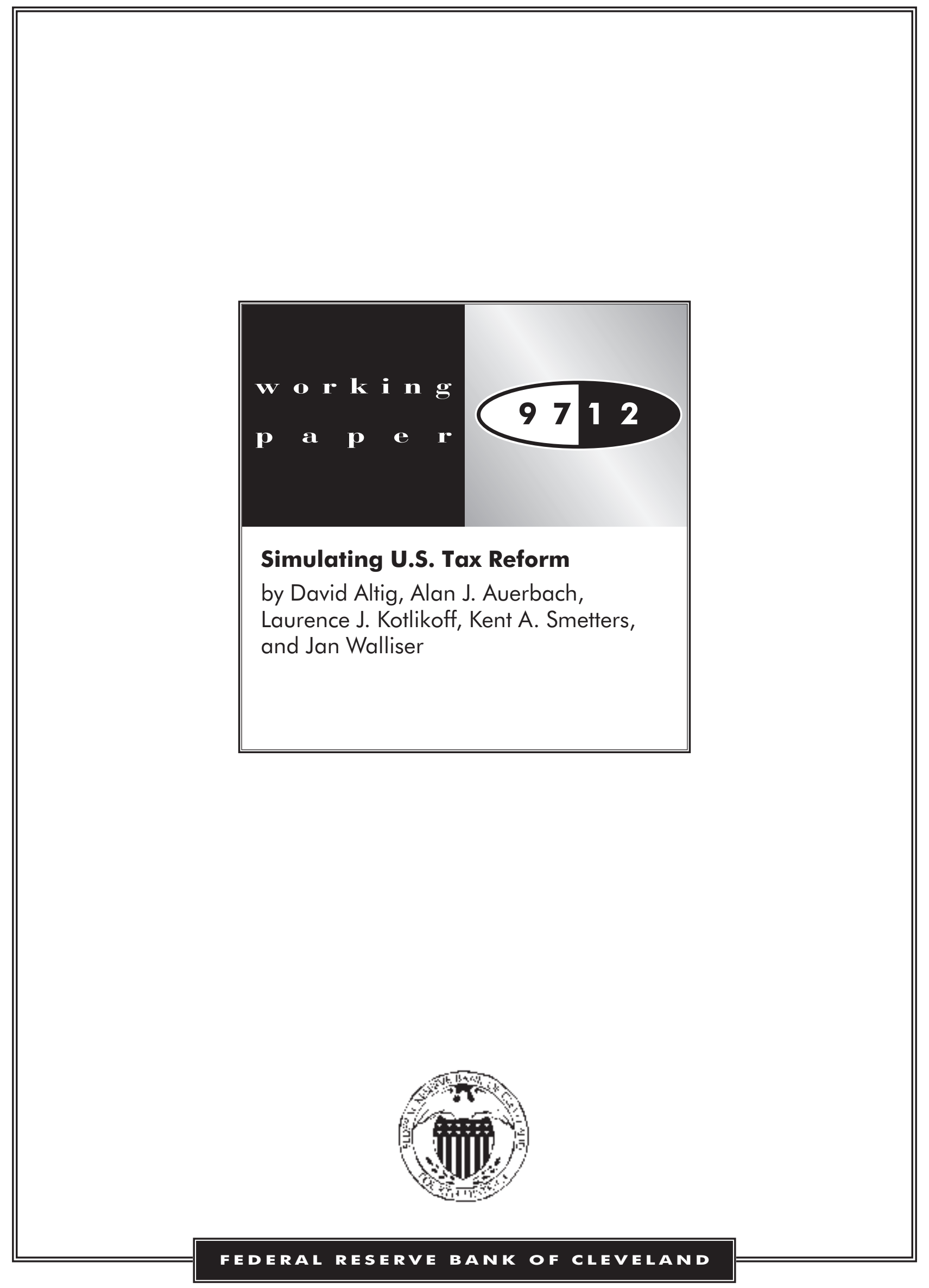




\title{
Simulating U.S. Tax Reform
}

by

\author{
David Altig \\ Federal Reserve Bank of Cleveland \\ daltig@clev.frb.org \\ Alan J. Auerbach \\ University of California, Berkeley and NBER \\ auerbach@econ.berkeley.edu
}

\section{Laurence J. Kotlikoff}

Boston University and NBER

kotlikof@bu.edu

Kent A. Smetters

Congressional Budget Office

kents@cbo.gov

and

Jan Walliser

Congressional Budget Office

janw@cbo.gov

\section{September 1997}

The views expressed here are those of the authors and do not necessarily reflect those of the Congressional Budget Office or the Federal Reserve Bank of Cleveland. 


\begin{abstract}
This paper uses a new large-scale dynamic simulation model to compare the equity, efficiency, and macroeconomic effects of five alternatives to the current U.S. federal income tax. These reforms are a proportional income tax, a proportional consumption tax, a flat tax, a flat tax with transition relief, and a progressive variant of the flat tax called the "X tax."

The model incorporates intragenerational heterogeneity and kinked budget constraints. It predicts major macroeconomic gains (including an 11 percent increase in long-run output) from replacing the federal tax system with a proportional consumption tax. Future middle- and upper-income classes gain from this policy, but initial older generations are hurt by the policy's implicit capital levy. Poor members of current and future generations also lose.

The flat tax, which adds a standard deduction to the consumption tax, makes all members of future generations better off, but at a cost of halving the economy's long-run output gain and harming initial older generations. Insulating these older generations through transition relief further reduces the long-run gains from tax reform. Switching to a proportional income tax without deductions and exemptions hurts current and future low lifetime earners, but helps everyone else. It also raises long-run output by over 5 percent. The $\mathrm{X}$ tax makes everyone better off in the long run and also raises long-run output by 7.5 percent. But it harms initial older generations who bear its implicit wealth tax.
\end{abstract}

JEL: $\mathrm{H} 20, \mathrm{C} 68$ 


\section{Introduction}

Tax reform has been and remains a hot issue, and for good reason. The U.S. tax structure is a hybrid of income- and consumption-tax provisions that is complex, distortionary, and replete with tax preferences. The 1997 tax bill introduced further complexity. In so doing, it provided further impetus for fundamental tax reform. ${ }^{1}$

As defined here, "Fundamental tax reform" means simplifying and integrating the tax code. Simplification, in turn, means eliminating most deductions and tax preferences in both the corporate and personal tax codes. Integration means applying common marginal rates to all sources of capital income, independent of the point of collection. Fundamental reform also limits opportunities for tax arbitrage.

Several current tax reform proposals certainly deserve to be called "fundamental." They include Hall and Rabushka's (1983, 1995) flat tax, the retail sales tax, and Bradford's (1986) X tax. The flat tax and the retail sales tax are two alternative ways of taxing consumption. The $\mathrm{X}$ tax also taxes consumption, but places high-wage earners in higher tax brackets than low-wage earners. Another fundamental reform option is moving to a broad-based, low-rate income tax.

\footnotetext{
${ }^{1}$ Auerbach and Slemrod (1997) argue that the problems of the 1981 tax reform prompted passage of the Tax Reform Act of 1986.
} 
This paper uses a computable general equilibrium simulation model to compare the equity, efficiency, and macroeconomic effects of fundamental tax reform. The model is a substantially enhanced version of the Auerbach-Kotlikoff (1987) dynamic life-cycle simulation model. ${ }^{2}$ The new model follows the lead of Fullerton and Rogers (1993) by incorporating intraas well as intergenerational inequality. Specifically, the model posits 12 different groups within each cohort, each with its own earnings ability (its own endowment of human capital).

Our new model approximates U.S. fiscal institutions much more closely than its predecessor. It includes an array of tax-base reductions, a progressive Social Security system, and a Medicare system. Incorporating tax-base reductions lets us analyze base broadening -- a key feature of current reform proposals. It also lets us use actual tax schedules in our calibration. $^{3}$ Leaving out these reductions would mean unrealistically low tax rates since the current income tax base covers only 57 percent of national income. ${ }^{4}$ The improved modeling of Social Security and Medicare also matters greatly. Both of these programs materially alter the intergenerational and intragenerational distributions of welfare.

Like Auerbach and Kotlikoff (1987), but unlike Fullerton and Rogers (1993) who assume myopic expectations, we compute the economy's perfect foresight transition path. Given the

\footnotetext{
${ }^{2}$ A similar model, used to consider only steady states, is presented in Altig and Carlstrom (1996).

${ }^{3}$ The Fullerton-Rogers Model, in contrast, assumes that all agents face the same marginal tax rate independent of income.

${ }^{4}$ See CBO (1997).
} 
magnitude of factor-price and tax-rate changes along our simulated transition paths, permitting agents to think rationally about the future is of great importance. This and other advantages vis a vis the Fullerton-Rogers model must be set against some disadvantages. Our model has a simpler production and preference structure than the Fullerton-Rogers model, which features multiple consumption and capital goods and industry-specific capital income taxation. The removal of inter-sectoral tax distortions can lead to non trivial changes in relative prices that differentially affect cohorts and earnings-groups within cohorts due to differences in their preference structures. This aspect of tax reform also entails efficiency gains, which are omitted in our analysis.

The model is used to examine five tax reforms. These reforms span the major proposals now under discussion. Each of the reforms replaces the federal personal and corporate income taxes, and each is simulated assuming the same growth-adjusted level of government spending and government debt. ${ }^{5}$ The reforms are a) a "clean" income tax, b) a "clean" consumption tax, c) a Hall-Rabushka flat tax, d) a Hall-Rabushka flat tax with transition relief, and e) a Bradford X tax.

The clean income tax eliminates all personal exemptions and deductions and taxes labor and capital income at a single proportional rate. The clean consumption tax differs from the clean income tax except by permitting 100 percent expensing of new investment. This tax is implemented as a wage tax at the household level and a cash-flow tax on businesses. The flat tax differs from the clean consumption tax by including a standard deduction against wage income

\footnotetext{
${ }^{5}$ To be precise, in each tax-reform simulation the levels of government purchases and outstanding debt are held constant through time when measured in effective units of labor.
} 
and by not taxing the implicit income from housing and consumer durables. The flat tax cum transition relief permits continued depreciation of old capital (capital in existence as of the reform). Finally, the $\mathrm{X}$ tax combines a progressive wage tax with a business cash-flow tax where the business cash-flow tax rate equals the highest tax rate applied to wage income.

Each of the reforms broadens the tax base by eliminating tax preferences under the current federal tax system. This permits a reduction in marginal tax rates on saving and labor supply. So too does the implicit tax on existing wealth that arises in four of the five proposals. The tax on existing wealth results from the favorable expensing afforded new capital. This tax preference for new capital reduces the value of existing capital relative to that of new capital. The expensing of new capital also effectively eliminates the taxation of capital income at the margin. The different income and substitution effects arising from these alternative tax reforms are the key to understanding the paper's results which are summarized as follows:

The clean income tax raises the long-run level of output by over 5 percent. It also generates sizable increases in the capital stock and the supply of labor. However, the reform hurts poor cohort members who face low federal income taxation in the current tax system due to its deductions and exemptions.

The clean consumption tax raises long-run output by almost 11 percent. The income effect associated with this tax reform reduces the welfare of the initial middle aged and elderly, but their losses mean more national saving, investment, and utility for most future generations. However, eliminating the progressivity of the existing tax structure lowers the welfare of the poorest members of society in the long run by roughly 4 percent. 
The flat tax's standard deduction alleviates some of the distributional concerns raised by the clean income and clean consumption taxes. But this deduction increases the tax rate needed to satisfy the government's intertemporal budget constraint. Consequently, the long-run output gain is only 6 percent. Although the flat tax's standard deduction insulates the poor from welfare losses, it hurts some middle-income groups alive in the early phase of the transition. Its capital levy also hurts initial high-income elderly cohorts. Those welfare losses must be set against the welfare gains enjoyed by all groups in the long run.

Adding transition relief to the flat tax limits the welfare losses of initial capital owners. But this modification of the flat tax reduces aggregate income gains further, with long-run output now rising by only 3.6 percent. Furthermore, because replacement tax rates must increase to compensate for the lost revenue associated with transition relief, all but the richest and poorest lifetime-income groups suffer welfare losses in the long run.

The $\mathrm{X}$ tax, which raises long-term output by 7.5 percent, provides no transition relief from its expensing provisions. It also hits the rich with higher marginal tax rates than the poor. It is not surprising, then, that the $\mathrm{X}$ tax helps those who are poor in the long run by more than it helps those who are rich. Still, under the $\mathrm{X}$ tax there are no long-run losers; even the rich are better off. The welfare gains for those alive in the long run range from 2 to 3 percent.

Fundamental reform of the US tax system can offer significant economic gains. However, those gains come at the sacrifice of certain groups. Transition relief and adjustments that prevent adverse distributional effects therefore mitigate the effects of tax reform on the economy. That result stems from a model that captures many but not all inefficiencies of the 
current tax system. Future research will show whether the addition of intra-sectoral distortions and compliance costs would alter that finding.

\section{The Model}

This section provides a general description of the new model and its method of solution.

\section{Demographic Structure}

The model's cohorts are distinguished by their dates of birth and their lifetime laborproductivity endowments. Each cohort includes 12 lifetime-earnings groups. Each of these 12 groups has its own initial endowment of human capital and its own pattern of growth in this endowment over its lifetime. The lifetime-earnings groups also differ with respect to their bequest preferences. All agents live for 55 periods with certainty (corresponding to adult ages 20 through 75), and each $j$-type generation is $1+n$ times larger than its predecessor. At model age 21 , each $j$-type cohort gives birth to a cohort of the same type. Population growth is exogenous, and each cohort is $(1+n)^{20}$ larger than its parent cohort.

\section{Preferences and Household Budget Constraints}

Each $j$-type agent who begins her economic life at date $t$ chooses perfect-foresight consumption paths $(c)$, leisure paths $(l)$, and intergenerational transfers $(b)$ to maximize a time-separable utility function of the form 


$$
\left.U_{t}^{j}=\frac{1}{1 \frac{1}{\gamma}}\left[\sum_{s=21}^{75} \beta^{s 21}\left(c_{s, t+s 21}^{j \frac{1}{\rho}}+\alpha l_{s, t+s 21}^{j}\right)^{\frac{1}{\rho}}\right)^{\frac{1}{\gamma} \frac{l}{\rho}}+\beta^{54} \mu^{j} b_{75, t+54}^{j \frac{l}{\gamma}}\right] .
$$

In (1) a is the utility weight on leisure, $\tilde{a}$ is the intertemporal elasticity of substitution in the leisure/consumption composite, and $\tilde{\mathrm{n}}$ is the intratemporal elasticity of substitution between consumption and leisure. The parameter $i^{j}$ is a $j$-type specific utility weight placed on bequests left to each child when the agent dies. The term $\hat{a}=1 /(1+\ddot{a})$ where $\ddot{a}$ is the rate of time preference, assumed to be the same for all agents.

Letting $a_{s, t}^{j}$ be capital holdings for type $j$ agents, of age $s$, at time $t$, maximization of (1) is subject to a sequence of budget constraints given by

$$
a_{s+1, t+1}^{j}=\left(1+r_{t}\right)\left(a_{s, t}^{j}+g_{s, t}^{j}\right)+w_{s, t}^{j}\left(E_{s, t}^{j} l_{s, t}^{j}\right)-c_{s, t}^{j}-\sum_{k=1}^{K} T^{k}\left(B_{s, t}^{j, k}\right) N b_{s, t}^{j} .
$$

$$
l_{s, t}^{j} \leq E_{s, t}^{j}
$$

where $r_{t}$ is the pretax return to savings, $g_{s, t}^{j}$ are gifts received from parents, $E_{s, t}^{j}$ is the time endowment, $b_{s, t}^{j}$ denotes bequests made to each of the $N=(1+n)^{20}$ children, and the functions $T^{k}(\cdot)$ with tax base $B_{s, t}^{j, k}$ as an argument determine net tax payments from income sources $k=1, \ldots, K$. All taxes are collected at the household level, and the tax system includes both a personal income tax and a business profits tax.

An individual's earnings ability is an exogenous function of her age, her type, and the level of labor-augmenting technical progress, which grows at a constant rate $\ddot{e}$. We concentrate 
all skill differences by age and type in an efficiency parameter $\stackrel{\circ}{s}_{s}^{j}$. Thus, the wage rate for an agent of type $j$ and age $s$ is $w_{s, t}^{j}=\stackrel{\circ}{a}{ }_{s}^{j} w_{t}$, where $w_{t}$ is the growth-adjusted real wage at time $t . \stackrel{\circ}{a_{s}^{j}}$ increases with age to reflect not only the accumulation of human capital, but also technical progress. To permit balanced growth for our specifications of preferences given the restriction on leisure shown in equation (2), we assume that technical progress also causes the time endowment of each successive generation to grow at rate $\ddot{e} .^{6}$ Thus, if $E_{s, t}^{j}$ is the endowment of type $j$ at age $s$ and time $t$, then $E_{s, t}^{j}=(1+\ddot{e}) E_{s, t-1}^{j}$, for all $s, t$, and $j$. Notice that the endowment $E_{s, t}$ ${ }^{j}$ depends only on an agent's year of birth. Because $E$ grows at rate ë from one cohort to the next, there will be no underlying trend in $w_{t}$.

Transfers are received by children, with interest, at the beginning of the period after they are made by their parents. We restrict all parental transfers to bequests, so that $b_{s, t}^{j}=0$, for $s \neq 75$, and $g_{s, t}^{j}=0$, for $s \neq 56$. In the steady state, therefore, $g^{j}=b^{j}$, for all $j$ (where we have dropped the age subscripts for convenience).

\section{The Government}

At each time $t$, the government collects tax revenues and issues debt $\left(D_{t+1}\right)$ which it uses to finance government purchases of goods and services $\left(G_{t}\right)$ and interest payments on the inherited stock of debt $\left(D_{t}\right)$. Letting $\ddot{o}^{j}$ be the fraction of $j$-type agents in each generation, the government's budget constraint evolves according to

\footnotetext{
${ }^{6}$ See Auerbach, et al. (1989) for a more complete discussion of this strategy for dealing with balanced
} growth. 


$$
D_{t+1}+(1+n)^{t} \sum_{j=1}^{12} \phi^{j} \sum_{s=21}^{75}(1+n)^{(s 2 l)} \sum_{k=1}^{K} T^{k}\left(B_{s, t}^{j, k}\right)=G_{t}+\left(1+r_{t}\right) D_{t} .
$$

Government expenditures are assumed to be unproductive and generate no utility to households. The values of $G_{t}$ and $D_{t}$ are held fixed per effective worker throughout the transition path. Any reduction in government outlays resulting from a change in the government's real interest payments is passed on to households in the form of a lower tax rate.

The model also has a social security system which incorporates Old-Age and Survivors Insurance (OASI), Disability Insurance (DI), and Medicare's Hospital Insurance (HI). Old-age benefits are calculated according to the progressive statutory bend-point formula while disability and Medicare benefits are provided as lump-sum transfers. The OASI payroll tax is set at 9.7 percent and applied to wage income up to a limit of $\$ 62,700$. HI and DI tax rates are set at 2.9 percent and 1.9 percent respectively. Like the OASI tax, DI contributions apply only to wages below $\$ 62,700$. The HI tax, in contrast, is not subject to an earnings ceiling.

Benefits are scaled to reflect spousal and survivor benefits using distributional information provided in the 1997 OASDI Trustees Report. We set the perceived marginal link between the OASI contributions and the OASI benefits at 25 percent. The perceived effective OASI tax rate is, thus, 7.3 percent -75 percent of 9.7 percent. $^{7}$ Lump-sum HI and DI benefits are provided on an equal basis to agents above and below age 65 , respectively.

\footnotetext{
${ }^{7}$ See chapter 10 of Auerbach and Kotlikoff (1987) for a more detailed discussion.
} 


\section{Firms and Technology}

Aggregate capital $(K)$ and labor $(L)$ are obtained from individual asset and labor supplies

as

$$
K_{t}=(1+n)^{t} \quad \sum_{j=1}^{l 2} \phi^{j} \quad \sum_{s=2 l}^{75}(1+n)^{(s 21)} a_{s, t}^{j} \quad D_{t}
$$

and

$$
L_{t}=(1+n)^{t} \sum_{j=1}^{12} \phi^{j} \sum_{s=21}^{75}(1+n)^{(s 21)} \varepsilon_{s}^{j}\left(E_{s, t}^{j} l_{s, t}^{j}\right)
$$

Output (net of depreciation) is produced by identical competitive firms using a neoclassical, constant-returns-to-scale production technology. The aggregate production technology is the standard Cobb-Douglas form

$$
Y_{t}=A K_{t}^{\theta} L_{t}^{1 \theta}
$$

where $Y_{t}$ is aggregate output (national income) and è is capital's share in production.

Some of our experiments assume costly adjustment of the capital stock. These costs are a simple quadratic function of investment:

$$
C\left(I_{t}\right)=\left[1+0.5 b\left(I_{t} / K_{t}\right)\right] I_{t}
$$

The competitive pre-tax, pre-expensing rate of return to capital at time $t$ is given by the marginal product of capital (defined in terms of the capital-labor ratio, $\hat{e}$ ) 


$$
r_{t}=\theta A \kappa_{t}^{\theta 1}
$$

In general, tax systems treat new and existing capital differently. Under the consumption tax, new capital is permitted immediate expensing, while existing capital receives no such deduction. Even under the existing income tax, the combined effect of accelerated depreciation and the lack of inflation-indexing makes the depreciation allowances per unit of existing capital lower than those given new capital. We model provisions that treat new and existing capital differently using the mechanism of fractional expensing of new capital, at rate $z$. That is, we set $z$ to account for the extent to which new capital faces a lower effective tax rate than does existing capital (with $z=1$ under the consumption tax). If $\hat{o}_{t}{ }^{K}$ is the time- $t$ marginal tax rate on capital income (net of expensing) then, given (7), arbitrage between new and existing capital implies that the latter has a unit value of

$$
q_{t}=\left(1 z_{t} \tau_{t}^{K}\right)+\left(1 \tau_{t}^{K}\right) b\left(I_{t} / K_{t}\right)
$$

assuming that adjustment costs are expensed. Equation (9) equals Tobin's $q$.

The arbitrage condition arising from profit-maximization implies that the post-tax return is:

$$
\tilde{r}_{t}=\frac{\left(r_{t}+0.5 b\left(I_{t} / K_{t}\right)^{2}\right)\left(1 \tau_{t}^{K}\right)+q_{t+1} q_{t}}{q_{t}} .
$$




\section{Calibration}

Much of our model's parameterization is relatively standard. Exceptions include earnings-ability profiles and the fiscal structure. We turn first to these elements and then discuss more familiar preference and technology parameters. Table 1 summarizes our selected parameters.

\section{Earnings-Ability Profiles}

The growth-adjusted earnings ability profiles in equation (5) are of the form

$$
\boldsymbol{\varepsilon}_{s}^{j}=e^{a \dot{b}+a j s+a j^{j} s^{2}+a j s^{3} s^{3}} .
$$

Values of the $a$ coefficients for $j$-type groups 1 through 12-in ascending order of lifetime income-are based on regressions fitted to the University of Michigan's Panel Study of Income Dynamics, using a strategy similar to that in Fullerton and Rogers (1993). The procedure involves (i) regressing the log of hourly wages on fixed-effect dummies, cubics in age, and interactions between age, age-squared, and a set of demographic variables; (ii) using the estimated coefficients from step (i) to generate predicted lifetime wage profiles; (iii) sorting the data according to the present-value of implied lifetime income and dividing the sorted data into the 12 classes according to lifetime-wage income; and (iv) estimating the coefficients of (11) from the simulated data profiles of each of the 12 groups.

In sorting the data for steps (iii) and (iv), the population was divided into deciles. Groups 1 and 12 comprise the bottom and top 2 percent of lifetime wage income earners, and groups 2 
and 11 the remaining 8 percent of the top and bottom deciles. All other groups constitute 10 percent of the population. For example, group 3 is the second decile of lifetime-wage income, group four the third decile, and so on up to group 10.

The estimated earnings-ability profiles, scaled to include the effects of technical progress, are shown in Figure 1. A detailed description of the procedure is provided in the Appendix. Given our benchmark parameterization, peak hourly wages valued in 1996 dollars are \$4.00, $\$ 14.70$, and $\$ 79.50$ for individuals in classes 1,6 , and 12 , respectively. More generally, steady-state annual labor incomes derived from the model's assumptions and from the endogenous labor supply choices range from $\$ 9,000$ to $\$ 130,000$. These calculations include labor compensation in the form of fringe benefits (discussed below).

\section{Government Spending and Debt}

The model includes government purchases of goods and services, government debt, and distortionary taxes. The level of government purchases, $G_{t}$, was chosen so that the benchmark steady-state ratio of government purchases to national income equals 0.214 . The level of government debt, $D_{t}$, was chosen such that the associated real interest payments equal about 3.5 percent of national income in the initial steady state. These values match the corresponding 1996 values for the combined local, state, and federal government in the United States. 


\section{The Benchmark Tax System}

The benchmark tax system in our initial steady state is designed to approximate the salient aspects of the 1996 U.S. (federal, state, and local) tax and transfer system. It features a hybrid tax system (incorporating wage-income, capital-income, and consumption tax elements) and payroll taxation for the Social Security and Medicare programs. To adjust for tax evasion, we reduce income taxes by 2.6 percent. This adjustment is consistent with the degree of tax evasion reported in Slemrod and Bakija (1996). In the various alternative tax structure experiments we assume that evasion reduces the post-reform tax base (income net of deductions and exemptions) by the same percentage as before the reform. Thus, the level of tax evasion falls when the tax base shrinks.

We approximate the hybrid current U.S. tax system by specifying a progressive wage-income tax, a flat capital-income tax, a flat state income tax, and a flat consumption tax.

\section{$\underline{\text { Wage Income Taxation }}$}

The wage-income tax structure has four elements: 1) a progressive marginal rate structure derived from a quadratic approximation to the 1996 federal statutory tax rates for individuals, 2) a standard deduction of $\$ 4000$ and exemptions of $\$ 5660$ (which assumes 1.2 children per agent, consistent with the model's population growth assumption), 3) Itemized deductions—applied only when they exceed the amount of the standard deduction-that are a positive linear function of income estimated from data reported in the Statistics of Income, ${ }^{8}$ and 4) Earnings-ability profiles that are scaled up to incorporate pension and fringe components of labor compensation. ${ }^{9}$

\footnotetext{
${ }^{8}$ The data used in this estimation was taken from all taxable returns in tax year 1993. The function was
} 


\section{Capital Income Taxation}

Following Auerbach (1996), we assume that income from residential capital and nonresidential capital are taxed at flat rates of 6 percent and 26 percent, respectively. Given the roughly equal amounts of these two forms of capital, the effective federal marginal tax rate on total capital income is 16 percent. However, this rate applies only to new capital. Existing capital faces a higher tax rate which, given depreciation schedules, is estimated to be 20 percent. We model this gap by assuming that all capital income faces a 20 percent tax, but that 20 percent of new capital may be expensed, thereby generating a 16 percent effective rate on new capital. In addition to the federal taxation, both capital and wage income are subject to a proportional state income tax of 3.7 percent.

\section{$\underline{\text { Consumption Taxation }}$}

obtained by regressing deductions exclusive of mortgage interest expense on the midpoints of reported income ranges. (The deduction of interest expense on home mortgages was included in our calculation of the capital-income tax rate, as we will subsequently describe.) The regression yielded a coefficient of 0.0755 with an $\mathrm{R}^{2}$ equal to 0.99 .

9 Benefits as a function of adjusted gross income were kindly provided by Jane Gravelle of the Congressional Research Service and Judy Xanthopoulos of the Joint Committee on Taxation, respectively. Based on this information we regressed total benefits on AGI. The regression yielded a coefficient of 0.11295 with an $\mathrm{R}^{2}$ equal to 0.99 . In defining the wage-tax base, we therefore exempt roughly 11 percent of labor compensation from the base calculations. 
Consumption taxes in the initial steady state reflect two elements of the existing tax structure. First we impose an 8.8 percent tax on consumption expenditures consistent with values reported in the National Income and Product Accounts on indirect business and excise revenues. However, because contributions to both defined benefit and defined contribution pension plans receive consumption tax treatment, we levy an additional 2.5 percent tax on household consumption goods expenditures to account for the indirect taxation of labor compensation in the form of pension benefits (Auerbach 1996). This 2.5 percent tax replaces the wage tax that otherwise would apply if pension contributions were taxed as income.

\section{Solving the Model}

The model is solved with a Gauss-Seidel algorithm. The calculation starts with a guess for certain key variables and then iterates on those variables until a convergence criterion is met. The identifying restrictions of the model are used to compute the remaining economic variables as well as the updates for the iterations. The solution involves several steps and inner loops that solve for household-level variables before moving to an outer loop which solves for the timepaths of aggregate variables including the capital stock and aggregate labor supply.

The household optimization problem is subject to the constraint that leisure not exceed the endowment of time (equation (2)). For those households who would violate the constraint, the model calculates shadow wage rates at which they exactly consume their full-time endowment.

The household's budget constraint is kinked due to the tax deductions applied against wage income. A household with wage income below the deduction level faces marginal and 
average tax rates equal to zero. A household with wage income above the deduction level faces positive marginal and average tax rates. Due to the discontinuity of the marginal tax rates, it may be optimal for some households to locate exactly at the kink. Our algorithm deals with this problem as follows. We identify households that choose to locate at the kink by evaluating their leisure choice and corresponding wage income above and below the kink. We then calculate a shadow marginal tax rate from the first-order conditions that puts those households exactly at the kink. This procedure generates optimal forward-looking leisure and consumption choices for all periods of life.

The payroll tax ceiling introduces additional complexity by creating a non-convexity in the budget constraint. For those above the payroll tax ceiling, the marginal tax rate on labor falls to zero. We evaluate the utility on both sides of the non-convex section and put households on the side that generates highest utility.

Aggregate variables of the model are solved with a forward-looking algorithm that iterates on the capital stock and labor supply over the entire transition path. An initial guess is made for the time-paths of these variables as well as for the shadow wage rates, shadow tax rates, endogenous tax rates, the payroll tax rate and the Social Security and Medicare wealth levels. For an initial guess of the time-path of these variables, the model calculates the corresponding factor prices and forward-looking consumption, asset and leisure choices for all income classes in each current and future cohort. Shadow wages and shadow taxes are calculated to ensure that the time endowment and the tax constraints discussed above are satisfied. Households' labor supply and assets are then aggregated by both age and lifetime income class at each period in time. This aggregation generates a new guess for the time-paths of the capital stock and labor 
supply. The tax rate which is endogenous for the particular simulation, is updated to meet the revenue-neutrality requirement. The payroll tax is also updated to preserve the pay-as-you-go financing of Social Security and Medicare benefits. ${ }^{10}$ The algorithm then iterates until the capital stock and labor supply time-paths each converge.

\section{The Benchmark Equilibrium}

Choices for the remaining technology, preference, and demographic parameters are summarized in Table 1. The benchmark values for ä, ã, $\tilde{\mathrm{n}}$, and $n$ are those in Auerbach and Kotlikoff (1987). The parameter á is chosen so that agents devote, on average, about 40 percent of their available time endowment (of 16 hours per day) to labor during their prime working years (real-life ages of roughly 21-55). The parameters $i^{j}$ are chosen to match bequests as a fraction of income in the initial steady state based on estimates by Menchik and David (1982) reported in Fullerton and Rogers (1993). Summary statistics for the initial steady state are provided in Table 2 .

Given our parameter choices, the model generates a pre-tax, pre-expensing interest rate of 9.3 percent, a net national saving rate of 5.3 percent, and a capital/national-income ratio of 2.6. Consumption accounts for 73.4 percent of national income, net investment for 5.2 percent, and government purchases of goods and services for 21.4 percent. These figures are close to their respective 1996 NIPA values.

\footnotetext{
${ }^{10}$ Note that the Social Security replacement rate and absolute level of Medicare benefits are exogenous.
} 
The calibrated model's initial economy-wide average marginal tax rate on wage income is 21.4 percent, close to the figure obtained from the NBER's TAXSIM model reported in Auerbach (1996). The average wage-income tax rate equals 12.1 percent. For all individuals in the highest lifetime income class (group 12), the average effective marginal tax rate on labor income is 28.6 percent. The highest realized effective marginal tax rate is 34 percent. For lifetime income class 6-whose members have peak labor earnings of about $\$ 35,000$ - the average tax rate and average marginal tax rate are 10.6 and 20.0 percent, respectively. For the poorest class (group 1), the corresponding rates are zero and 5.5 percent. $^{11}$

\section{Tax-Reform Experiments}

The various tax-reform experiments were described in the introduction and are summarized in Table 3. Except for the indicated changes to federal income taxes, each experiment leaves the elements of the benchmark tax structure intact. In all of the experiments, we take 1996 as our initial steady state, consistent with our chosen initial tax schedules and tax bases. This section abstracts from capital-stock adjustment costs (that is, we set $b=0$ in (7)).

\footnotetext{
${ }^{11}$ The average marginal rate for people with the lowest income exceeds zero due to positive shadow tax rates in peak earnings years.
} 


\section{A Clean Income Tax}

Our first experiment replaces the progressive taxation of wage income with a single rate that is also applied to capital income. In addition, the clean income tax eliminates the major federal tax-base reductions including the standard deduction, personal and dependent exemptions, itemized deductions, the deductibility of state income taxes at the federal level, and preferential tax treatment of fringe benefits. The latter is implemented by decreasing the consumption tax rate by 0.025 and subjecting all compensation to the new proportional income tax. The investment expensing rate remains at its initial 20 percent level.

Aggregate results from the clean income-tax reform are summarized in Table 4. The marginal tax rates required to satisfy the government's budget constraint are close to 13 percent over the entire transition path. This value lies below both the 21.4 percent average marginal rate applied to labor income and the 16 percent rate applied to capital income in the benchmark steady state. National income rises by 4.5 percent immediately and by 5.4 percent ultimately. In the early years of the transition, these output changes are dominated by increased work effort associated with the lower marginal tax rates. In the long run, higher wealth levels mitigate some of the increase in labor supply. However, the accumulated effects on saving from lower capital-income rates more than compensate for the lower labor supply: In the long run the capital stock increases by just over 7.5 percent. The short-run decrease in the capital-labor ratio produces the short-run increase in the before-tax interest rate and short-run decrease in before-tax wage rate. The long-run increase in the capital-labor ratio produces the long-run reversal of these variables. The effect of this tax reform on the value of stock market (measured via Tobin's $q$ ) is small because the level of expensing has not changed and the effective tax rate on capital income 
has decreased only slightly (housing capital is no longer exempt).

Figure 2 shows the effects of the tax reform on remaining lifetime utility for different generations by lifetime-income group. For ease of exposition, the figure reports the utility gains only for classes $1,3,6,9$ and 12 . The horizontal axis of the figure measures the period of birth for the relevant generation relative to the period of the regime shift (period 1). For example, 0 refers to the generation born just prior to the regime shift, 1 to the generation born in the period of the shift, 2 in the following period, and so on. The change in remaining lifetime utility is measured as the equivalent variation of remaining full lifetime income. In interpreting these numbers, one should keep in mind that full lifetime income includes the value of leisure. Full lifetime income, in our model, is more than twice the size of remaining actual lifetime earnings. Hence, the utility gains or losses for any cohort will tend to be larger in magnitude if measured relative to either realized earnings or relative to consumption.

In the long run, only members of lifetime-income groups 7 through 12 benefit from the clean income-tax reform, the rise in aggregate output notwithstanding. The main reason is that average tax rates increase for income classes 1 through 6 due to the loss of deductions and exemptions. In the short run, however, all agents who are 50 years (real age 70) and older at the time of the reform benefit slightly since the reform increases the after-tax return to capital. 


\section{A Clean Consumption Tax}

Our clean consumption tax differs from the clean income tax by including full expensing of investment expenditures. This produces a consumption-tax structure. Formally, we specify the system as a combination of a labor-income tax and a business cash-flow tax. Table 5 summarizes aggregate effects. The clean consumption tax produces the equivalent of a one-time tax on the existing capital stock. It does so by lowering the value of the existing capital stock relative to new capital, as reflected in the large drop in $q$.

The wealth effects for holders of old capital associated with the drop in $q$ work in combination with lower marginal tax rates to bring about a substantial increase in aggregate short-run labor supply. In the period just after the tax reform, labor supply increases by almost 8.5 percent. At the same time, the saving rate responds strongly to the capital levy and to the removal of the capital-income tax on marginal investment. The saving rate rises immediately from 5.3 percent to near 10 percent. As the initial negative wealth effects and labor supply responses diminish over time, the accelerated capital accumulation leads to higher levels of output. The saving rate eventually recedes to 6.2 percent. Five years after the reform, the capital stock (per effective unit of labor) is more than 10 percent higher than its initial steady state value, and output is 8 percent higher. In the long run, the capital stock exceeds its initial value by 31.1 percent, and output its initial value by almost 11 percent. 
The strong response of output and labor income from the shift to consumption taxation allows the replacement tax rate to fall over time. The initial replacement tax rate is 14 percent, which is higher than any of the rates associated with the clean income tax. However, in the long run, the consumption-tax rate falls to 12.5 percent, which is slightly lower than the long-run rate for the clean income tax.

Figure 3 shows that, despite the large aggregate income gains, lower lifetime-income groups are hurt by the reform. Although these losses are not as large as those in the clean income-tax case-indeed, several groups switch from being long-run utility losers to long-run utility winners - the regressive nature of the outcomes persists. Figure 3 also reveals the substantial welfare loss for the owners of old capital. The loss is larger for richer agents who own the larger share of the capital stock. The exception to this finding are the poorest agents (group 1) of age 45 and above (real-age 65 and above). Their welfare gains can be explained by two factors. First, this group consumes almost entirely out of social security, which is protected from the change in asset values. Second, the poorest borrow against some of their social security benefits earlier in life and their slightly negative net worth shrinks due to the policy-induced fall in the value of existing capital. 


\section{The Flat Tax}

Our flat tax experiment modifies the clean consumption tax by including a standard deduction of $\$ 9500$. In addition, housing wealth, which equals about half of the capital stock, is entirely exempt from taxation. The levy on housing wealth under the consumption tax played a large role in explaining the sharp jump in the short-run labor supply. Exempting housing from taxation is an important modification, however, because it is unlikely that policy makers would seriously consider taxing housing.

Table 6 reports aggregate results. The need to finance the standard deduction and tax sheltering of old housing capital increases the replacement tax rates above those of the clean consumption tax. As a result, the output effects under the flat tax are reduced relative to its proportional counterpart. The long-run rise in the capital stock and level of output are, respectively, only 68 and 56 percent as large as those under the clean consumption tax. The labor supply response is lower as well, reflecting both the higher short- and long-run levels of marginal tax rates and the much smaller wealth effect on labor supply that results from protecting the existing housing stock from the cash flow tax. ${ }^{12}$ The revenue-neutral flat-tax rate equals 22 percent initially and reaches 19.4 percent in the long run. However, it takes 10 years for the tax rate to fall below 21 percent and another 11 years for the tax rate to fall below 20 percent.

The flat tax generates long-run utility gains across-the-board. Interestingly, the highest relative gains are for the richest and poorest lifetime-income groups. The utility changes for the richest and poorest lifetime-income groups also differ from those of the middle groups

\footnotetext{
12 This latter effect can be seen by the less dramatic decline in the value of $q$.
} 
throughout the entire transition path. Group 12 benefits most from reduced marginal and average tax rates. Group 1, which pays very little taxes under either regime, benefits from the overall increase in wages. For those in income groups 3 through 9, the marginal and average tax rates initially change little or even rise. This stems from the revenue neutrality of the experiment which requires a flat-tax marginal rate that initially exceeds the pre-reform tax rates for some agents in the middle-income classes in order to finance the lower tax rates at the top end. Those who belong to the lifetime middle-income range and enter the workforce close to the time of reform suffer utility losses along the transition path. They face relatively high tax rates of 20 to 22 percent on labor income for 20 to 25 years of their working life before the growth of the capital stock becomes fully effective. Once the economy grows, though, tax rates fall and wages rise, which raises the lifetime utility levels of groups 3 through 9.

Neither the macroeconomic variables nor the welfare results of the flat tax experiment are influenced by the existence of a joy-of-giving bequest motive. We repeated the simulation by turning off bequests (setting the utility bequest weight $i^{j}=0$ for all $j$ ) and found no significant differences in the initial steady-state computations nor in the post-reform changes in output or welfare. $^{13}$

\footnotetext{
${ }^{13}$ The results for this experiment, available from the authors, are not reported.
} 


\section{Flat Tax with Transition Relief}

Our fourth experiment adds transition relief to the flat tax by extending pre-reform depreciation rules for capital in place at the time of the tax reform. Since the present value of depreciation allowances equals roughly 50 percent of the current capital stock, transition relief is modeled by cutting the effective cash-flow tax rate in half.

As seen in Table 7, all of the salutary long-run aggregate effects of the standard flat tax are mitigated by the introduction of transition relief. Still, the capital stock increases by over 15 percent in the long run, affording a 3.5 percent rise in the long-run level of output. Labor supply changes little following this tax reform, and then actually declines below its initial steady-state level, reflecting both higher marginal tax rates (on average) and smaller wealth effects.

Figure 5 shows that transition relief leads to smaller short-run welfare losses for current wealth holders but at the cost of smaller welfare gains for future generations. The provision of transition relief actually reinforces the utility losses for the mid-range lifetime-income groups along the transition path, turns positive gains for some individuals in the no-transition-relief case to losses, and reduces the utility gains for those groups for whom positive welfare effects remain.

\section{The X tax}

Bradford's X tax, using the present-law standard deduction, maintains the progressivity of the present-law wage tax schedule but raises the levy on old capital by setting the cash flow tax rate 
to the highest marginal tax rate applied to labor income-in this case, 30 percent—along with full expensing of new investment. ${ }^{14}$ The large wealth levy allows the elimination of capital income from the tax base and the protection of housing wealth (which reduces the effective cashflow tax rate to 15 percent). Nonetheless, as shown in Table 8, this reform still produces large long-run output gains despite maintaining progressive wage taxation. Only the clean consumption tax generates larger long-run output gains.

The long-run welfare effects of the $\mathrm{X}$ tax are quite progressive. As shown in Figure 6, the long-run gains vary inversely with lifetime income. Over the short run, those who are older and belong to the highest income class at the time of the reform suffer the largest welfare loss, reaching almost 7 percent of remaining lifetime utility since they hold the largest amount of real assets. The

poorest elderly, on the other hand, actually benefit from the capital levy since they live essentially on their social security benefits which are, in fact, a source of a slight amount of borrowing.

${ }^{14}$ Recall that marginal wage-tax rates are a linear function of taxable labor income. The adjustments required to maintain budget balance are implemented by changing the intercept of this function, while holding the slope constant. 
We repeated this simulation with a flat replacement wage tax while maintaining the present-law deduction. The cash-flow tax on capital income was held fixed at 30 percent in order to capture the effects of only flattening the wage tax. ${ }^{15}$ We found an increase in national income relative to the standard $\mathrm{X}$ tax (9.4 percent versus 7.5 percent) along with an increase in the long-run utility levels for all the top half of the income classes along with smaller increases for the bottom half. Agents born into income groups 3 - 5 around the time of the reform (year 1), however, incur a slightly smaller increase in their lifetime utility under this reform relative to the standard $\mathrm{X}$ tax (about a 0.1 percent decline). The long-run distribution of welfare gains however becomes less progressive with class 12 being the biggest winner, followed by classes 1, 9, 6, and 3.

\section{Some Sensitivity Analysis}

This section considers three alternative parameterizations of the standard (no transition relief) flat-tax reform. In the first simulation, we introduce investment adjustment costs. In the second simulation, we consider a smaller intertemporal elasticity of substitution. In the third simulation, we reduce the intratemporal elasticity of substitution. For each case, we recalibrate the initial steady state by changing either the pure rate of time preference or the utility-weight on leisure. The recalibration is required to start from a steady state with the same essential characteristics. The specifics of these changes are indicated in Table 9. The simulation results are reported in Tables 10-12 and Figures 7-9. Each of these changes reduces the degree to which

\footnotetext{
15 The results for this experiment, available from the authors, are not reported.
} 
agents react to changes in incentives, thereby dampening the macroeconomic impact of the tax reform.

The importance of wealth effects is reinforced once again in the adjustment cost experiment (Table 10; Figure 7). Because the presence of investment adjustment costs makes new capital relatively less attractive, $q$ does not drop as much following the introduction of full expensing as in the benchmark scenario without such costs. This cuts the initial labor supply response almost in half and leads to less growth in the capital stock in the long run.

The experiment with a smaller intratemporal elasticity of substitution looks quite similar to the flat-tax case under our benchmark parameterization in the early stages of the transition path (Table 11; Figure 8). However, in the long run, the decreased willingness to substitute higher consumption for leisure results in a decline in aggregate labor supply. Nevertheless, due to the sizable increase in the capital stock, the real-wage growth is as large as in the original flat-tax experiment.

Finally, a smaller intertemporal elasticity of substitution makes people less willing to reallocate consumption and leisure to different time periods after a change in wages and interest rates (Table 12; Figure 9). As a consequence, the one-time capital levy and the corresponding lower taxes on other factor income are less effective in inducing higher saving and labor supply immediately after the reform and lead to less long-run capital accumulation and labor supply.

Notice that the smaller expansion of output in the case with adjustment costs and a lower intertemporal elasticity of substitution transforms the long-run welfare gains for the groups with middle incomes into long-run welfare losses. 


\section{Concluding Remarks}

Proponents and opponents of fundamental tax reform wrestle with the same question: Are the gains to the winners worth the costs to the losers? This paper does not answer such questions. But it does try to give both sides a better basis for their answers. The paper's method is to simulate a much-improved version of the Auerbach-Kotlikoff model—one that considers intraas well as intergenerational equity and one that is closely calibrated to U.S. fiscal institutions and tax policy.

The model predicts significant long-run macroeconomic gains, including an 11 percent increase in output, from replacing the current U.S. federal tax system with a proportional consumption tax. For middle- and upper-income classes alive in the long run, this policy is a big winner. But older transition generations suffer from the imposition of an implicit capital levy, and low-income individuals, even in the long run, suffer a loss equal to about 4 percent of their full lifetime resources as growth fails to compensate for the decline in tax progressivity.

The flat tax, which modifies the basic consumption tax by exempting housing wealth from taxation and by providing a large wage-tax deduction, makes all long-run cohort members better off, but at a cost of nearly halving the economy's long-run output gain, from 11 percent to 6 percent. Even then, this reform leaves initial older generations worse off. Insulating these generations with transition relief, in the form of maintaining present-law depreciation allowances on existing capital, reduces the long-run output gain still further to 3.6 percent.

Other reforms produce similar tradeoffs. Switching to a clean proportional income tax is a loser for current and future low lifetime earners but a winner for everyone else. It also raises 
long-run output by over 5 percent. The $\mathrm{X}$ tax, which combines consumption-tax and progressive wage-tax elements, makes everyone better off in the long run and also raises output by 7.5 percent. But this reform harms initial older generations who face an implicit tax on their wealth.

To conclude, fundamental reform of the current U.S. tax structure offers the possibility of significant macroeconomic gains, but not without true sacrifice by certain groups. Adjustments that attempt to prevent adverse distributional effects yield much more modest aggregate effects. This, at least, is the view from a model that captures many, but certainly not all, of the inefficiencies of the current system. Expanding the current model to incorporate inter-asset and inter-sectoral tax distortions as well as enforcement and compliance costs could well alter this view, but that task remains for future research. 


\section{References}

Altig, David, and Charles T. Carlstrom, "Marginal Tax Rates and Income Inequality in a LifeCycle Model,” Working Paper, Federal Reserve Bank of Cleveland, June 1996.

Auerbach, Alan J., "Tax Reform, Capital Accumulation, Efficiency, and Growth," in: Henry J. Aaron and William G. Gale, eds., Economic Effects of Fundamental Tax Reform, The Brookings Institution: Washington, D.C., 1996.

Auerbach, Alan J. and Laurence J. Kotlikoff, Dynamic Fiscal Policy, Cambridge University Press: Cambridge, 1987.

Auerbach, Alan J., Laurence J. Kotlikoff, Robert P. Hagemann, and Giuseppe Nicoletti, “The Economic Dynamics of an Ageing Population: The Case of Four OECD Countries," OECD Economic Studies, Spring 1989, 51-96.

Auerbach, Alan J. and Joel Slemrod, "The Economic Effects of the Tax Reform Act of 1986," Journal of Economic Literature, June 1997.

Bradford, David, Untangling the Income Tax, Harvard University Press: Cambridge, MA, 1986.

Congressional Budget Office, Comparing Income and Consumption Tax Bases, CBO Paper, July, 1997.

Fullerton, Don and Diane Lim Rogers, Who Bears the Lifetime Tax Burden? The Brookings Institution: Washington, D.C., 1993.

Hall, Robert E. and Alvin Rabushka, The Flat Tax, Hoover Institution Press: Stanford, 1983.

Hall, Robert E. and Alvin Rabushka, The Flat Tax, 2nd edition, Hoover Institution Press: Stanford, 1995.

Menchik, Paul L. and Martin David, "The Incidence of a Lifetime Consumption Tax." National Tax Journal, 35, 1982, 189-203.

Slemrod, Joel and Jon Bakija, Taxing Ourselves: A Citizen's Guide to the Great Debate over Tax Reform, MIT Press: Cambridge, MA, 1996. 


\section{Table 1. Benchmark Parameter Definitions and Values}

Symbol Definition Value

\section{Preferences}

$\begin{array}{lll}\text { á } & \text { Utility weight on leisure } & 1.00\end{array}$

$\ddot{a} \quad$ Rate of time preference $\quad 0.015$

$\begin{array}{lll}\tilde{a} & \text { Intertemporal substitution elasticity } & 0.25\end{array}$

$\mathrm{i}^{\mathrm{j}} \quad$ Utility weight placed on bequests by income class $j \quad$ [1]

$\begin{array}{lll}\tilde{n} & \text { Intratemporal substitution elasticity } & 0.80\end{array}$

Human Capital

$j \quad$ Productivity of agent in income class $j$ at age $s$.

\section{DEMOGRAPHICS}

$n \quad$ Population growth 0.01

$N \quad$ Number of children per adult, $(1+n)^{20}$

$\ddot{o}^{\mathrm{j}} \quad$ Fraction of agents of income class $j$

\section{TECHNOLOGY}

$\begin{array}{lll}\text { ë } & \text { Technological change } & 0.01\end{array}$

$b \quad$ Adjustment cost parameter $\quad 0.00$

$\begin{array}{ll}\text { è Net capital share } & 0.25\end{array}$

\section{DebT, TaXes, Deductions in Initial Steady State}

- Debt service as fraction of National Income

- Disability Insurance tax rate

0.0190

- $\quad$ Medicare (HI) tax rate

- Social Security (OASI) tax rate

- Social Security replacement rate

- Social Security marginal tax-benefit linkage

$\hat{\mathrm{o}}^{\mathrm{W}}(\cdot) \quad$ Progressive wage tax with deductions and exemptions

$\hat{o}^{\mathrm{Y}} \quad$ State proportional income tax less evasion adjustment

[5]

\begin{tabular}{llr}
- & Reduction of wage base from itemized deductions & $0.0755^{[6]}$ \\
\hline & $\quad$ Reduction of wage base from fringe benefits $^{[6]}$ & $0.1129^{[6]}$ \\
Expensing $^{[7]}$ & 0.20 \\
\hline
\end{tabular}

Footnotes:

[1] Calibrated endogenously in the initial state to match the level of bequests-as a fraction of mean national income-in Fullerton and Rogers (1993, Table 3-8), in 1996 dollars.

[2] See Appendix for estimation procedure.

[3] $\ddot{o}^{1}=0.02, \ddot{o}^{2}=0.08, \ddot{o}^{i}=0.10(3 \leq i \leq 10), \ddot{o}^{11}=0.08, \ddot{o}^{12}=0.02$

[4] The statutory progressive bendpoint formula for 1996, scaled up by a factor of 2 to account for the fact that other non-DI benefits (mainly spousal and survivors benefits) account for $50 \%$ of all benefits paid (see 1996 OASDI Trustees Report, Table II.C7).

[5] The 1996 statutory tax function for a single individual with a deduction equal to $\$ 9661$ ( $\$ 4,000$ standard deduction, $\$ 2,550$ personal exemption and $\$ 2,550 \cdot \mathrm{N}$ exemption for dependents).

[6] Total proportional base reduction above the standard deduction therefore equals 0.18845 . 
Table 2. Key Endogenous Equilibrium Values for the Initial Steady State and the Corresponding Empirical Values

\begin{tabular}{lllll}
\hline \multicolumn{2}{c}{ Model } & & & Empirical Estimate and Calculation \\
\cline { 1 - 1 } \cline { 5 - 6 } Concept & Value & & Estimate Calculation (using NIPA unless indicated) \\
\hline
\end{tabular}

\section{Composition of National InCOMe (Percent)}

Personal Consumption $\quad 0.734 \quad 0.720$ Personal consumption expenditures - housing services

Net Saving Rate $\quad 0.053 \quad 0.056$ (National saving - capital consumption allowance)/NI

Government Purchases $\quad 0.214 \quad 0.212$ Consumption expenditures + gross investment for federal (defense and nondefense) and state and local consumption of fixed capital

\section{TAX RATES AND GOVERNMENT REVENUE}

Avg. Marginal Wage Tax ${ }^{[1]} \quad 0.214$

0.217 Auerbach (1996) based on the NBER TAXSIM model.

Government Revenue

0.239

OASDHI Tax

0.145

0.239 Total receipts - contributions for social insurance property taxes (state and local)

0.1471996 tax rate is 15.3 which includes trust fund contributions equal to about 0.6 .

\section{CAPITAL-OUtPUT RATIO AND BEFORE-TAX INTEREST RATE}

\begin{tabular}{lcc} 
Capital-Income Ratio & 2.564 & $\begin{array}{r}2.660 \\
1993 \text { current-cost net stock of fixed reproducible } \\
\text { wealth in the Survey of Consumer Finance - gov't } \\
\text { owned fixed capital / 1993 National Income }\end{array}$ \\
Before-Tax Rate of Return ${ }^{[3]} \quad 0.097 \quad \begin{array}{l}0.093 \\
\text { The 1960-1994 average of the sum of interest, } \\
\text { dividends, retained earnings and all corporate taxes } \\
\text { divided by the replacement value of capital stock } \\
\text { (Rippe, 1995). }\end{array}$ \\
\hline
\end{tabular}

Footnotes:

[1] Does not include the payroll tax.

[2] The social marginal rate of return (i.e., before corporate taxes). 
Table 3. Key Elements of Tax Reform Experiments

Experiment Description

"Clean" Income Tax

"Clean" Consumption Tax

Flat Tax (Standard)

Flat Tax (Transition Relief)

$\mathrm{X}$ Tax

\section{Eliminate all Tax Base Reductions}

Eliminate the standard deduction, personal exemption, exemptions for dependents, itemized deductions, preferential tax treatment of all fringe benefits (the consumption tax treatment of pension and the deductibility of non-pension benefits), and the deductibility of state income taxes at the federal level. ${ }^{[1]}$

Flattening of Tax Rates

Replace progressive wage tax and proportional capital income tax with a proportional equal tax rate on wage and capital income. Eliminate double taxation of capital income.

\section{Eliminate all Tax Base Reductions \\ Flattening of Tax Rates \\ Full Expensing}

Allow the deductibility of all new investment.

\section{Eliminate all Tax Base Reductions \\ Flattening of Tax Rates \\ Full Expensing \\ Protection of Housing Wealth}

Housing (including consumer durables) remain untaxed. ${ }^{[2]}$

Standard Deduction

Allow for a deduction for a single individual equal to $\$ 9,500$.

\author{
Eliminate all Tax Base Reductions \\ Flattening of Tax Rates \\ Full Expensing \\ Protection of Housing Wealth \\ Standard Deduction \\ Transition Relief \\ All existing assets continue to receive depreciation \\ allowances. ${ }^{[3]}$
}

Eliminate all Tax Base Reductions

Preserve Current-Law Progressive Wage Tax ${ }^{[4]}$

Capital Income Tax Set at Highest Marginal Wage Tax Rate

Full Expensing

Protection of Housing Wealth ${ }^{[5]}$

Footnotes:

[1] The consumption tax treatment of pensions is eliminated by decreasing the consumption tax by 0.025 and subjecting all compensation to the new proportional income tax.

[2] About 50\% of the capital stock is composed of housing and consumer durables which will not be taxed. Hence, the proportional tax rate on capital income is set to $1 / 2$ of the tax rate on wage income.

[3] As noted in Auerbach (1996, footnote 46), the current-law (with current inflation) present value of remaining depreciation allowances per dollar of net nonresidential capital is approximately half the value of the assets. Allowing for these depreciation allowances has the same impact as forgiving half of the cash-flow tax on existing assets. Hence, the cash flow tax on capital income is set to $1 / 4$ of the replacement proportional wage tax rate.

[4] General equilibrium effects and the constant government revenue constraint requires proportional shifts in the wage tax schedule (with an increase in the short run and a decrease in the long run). The average marginal tax rate is reported in Table 8.

[5] Since the highest marginal wage tax rate in the final steady state equals about 0.30 , the capital income tax is set equal to 0.15 . 
Figure 1 Earnings-Ability Profiles

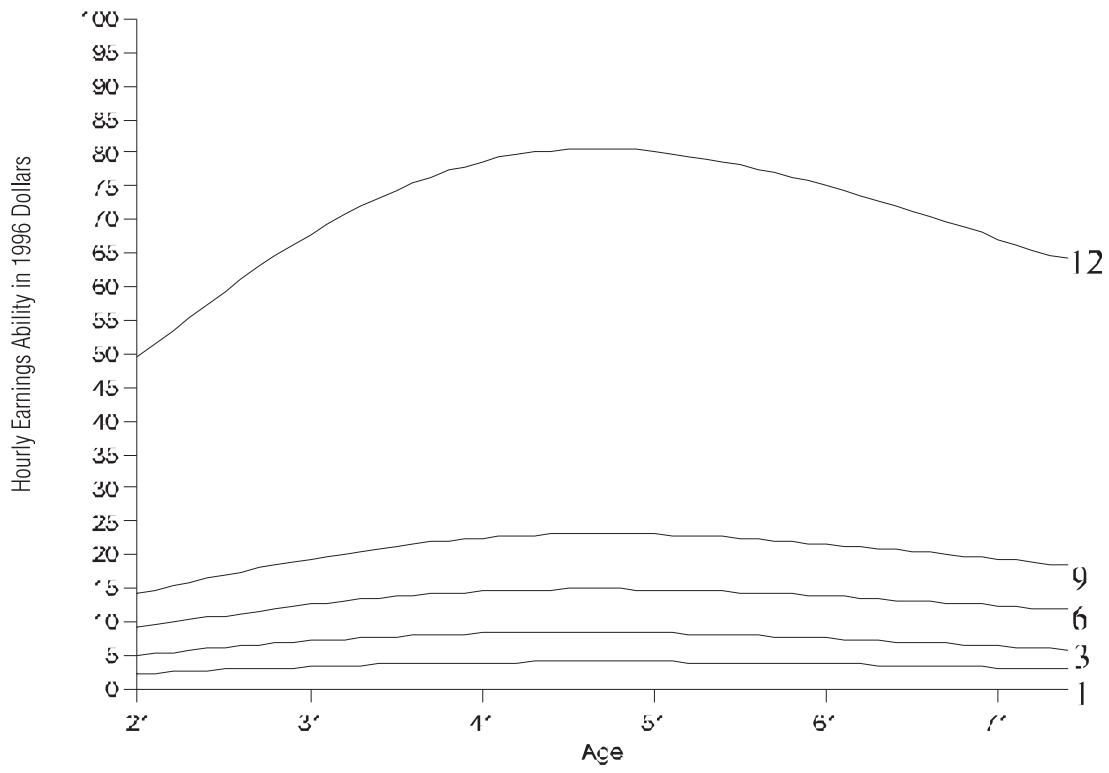


Table 4. "Clean" Flat Income Tax

$1996 \quad 1997 \quad 1998$

$2000 \quad 2001-2002$

2003

2004

2005

2010

2025

2055

2145

Composition of National Income

Consumption $^{[1]}+$

0.734

0.053

0.762

0.764

0.765

Net Investment ${ }^{[1]}+$

0.214

0.069

0.068

0.068

$0.767 \quad 0.768$

0.769

0.771

0.772

Government $^{[1]}=$

$1.000 \quad 1.045$

$0.214 \quad 0.214$

$0.067 \quad 0.066$

0.065

0.065

0.064

0.773

0.214

National Income ${ }^{[2]}$

1.046

1.047

$0.214 \quad 0.214$

0.214

0.214

0.214

0.063

0.778

0.784

0.785

0.785

Capital Stock, Labor Supply and Total Labor Income

Capital Stock ${ }^{[2]}$

Labor Supply ${ }^{[2]}$

Labor Income ${ }^{[2]}$

$1.000 \quad 1.006 \quad 1.012$

1.012

$1.000 \quad 1.058$

1.057

$1.018 \quad 1.024$

(1.049.

$1.049 \quad 1.050$

0.214

0.061

0.056

0.056

0.056

$1.000 \quad 1.045$

1.046

1.057

1.038

$1.054 \quad 1.055 \quad 1.054$

\title{
Net Saving Rate
}

Net Saving Rate

\begin{abstract}
$0.053 \quad 0.066$
\end{abstract}
0.065

1.047

$1.047=1.049$

1.054

1.050

1.042
1.053

1.060

1.050

1.050

1.051

1.053

1.048

$1.048 \quad 1.048$

Factor Prices: Wage Rate and Interest Rates

Before-Tax Wage

After-Tax Wage ${ }^{[3}$

$0.775 \quad 0.827$

0.989

0.065

$0.064 \quad 0.063 \quad 0.062$

$0.062 \quad 0.061$

0.060

0.058

0.054

0.053

0.053

Before-Tax Rate of Return

After-Tax Rate of Return

$0.097 \quad 0.101$

0.828

$0.991 \quad 0.992 \quad 0.994$

0.995

0.996

0.997

0.998

1.002

1.006

$1.007 \quad 1.007$

$\begin{array}{lllllll}0.836 & 0.837 & 0.838 & 0.843 & 0.847 & 0.848 & 0.848\end{array}$

Unified Government Debt

$\operatorname{Debt}^{[2]}$

$1.000 \quad 1.000$

$0.087 \quad 0.07$

0.087

$0.086 \quad 0.086$

0.086

0.085

0.085

0.085

0.084

$0.083 \quad 0.083 \quad 0.083$

Dynamic Replacement Income Tax Rate

\author{
Tax Rate ${ }^{[4]}$
}

n/a $\quad 0.133$

1.000

1.000

$1.000 \quad 1.000 \quad 1.000$

$\begin{array}{lllllll}1.000 & 1.000 & 1.000 & 1.000 & 1.000 & 0.999 & 1.000\end{array}$

Tax Revenue and the Endogenous OASDI-HI Pavroll Tax

\begin{tabular}{|c|c|c|c|c|c|c|c|c|c|c|c|c|c|c|}
\hline & & & & & & & & & & & & & & \\
\hline Revenue $^{[5]}$ & 0.239 & 0.240 & 0.240 & 0.240 & 0.239 & 0.239 & 0.239 & 0.239 & 0.239 & 0.239 & 0.239 & 0.238 & 0.238 & 0.238 \\
\hline ayroll Tax Rate & 0.147 & 0.141 & 0.141 & 0.141 & 0.141 & 0.141 & 0.141 & 0.141 & 0.141 & 0.141 & 0.142 & 0.143 & 0.144 & 0.144 \\
\hline
\end{tabular}

Payroll Tax Rate

$0.147 \quad 0.14$

0.141

0.141

$1.000 \quad 1.009$

1.010

1.010

$1.010 \quad 1.010 \quad 1.010$

1.010

1.010

1.010

1.010

1.010

1.010

Footnotes:

[1] The components of national income (NI) sum to income (i.e., they are not percentages of NI except, of course, for year 1996 when NI $=1.0$ ).

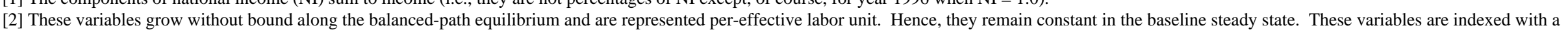
baseline value of 1.00 in 1996

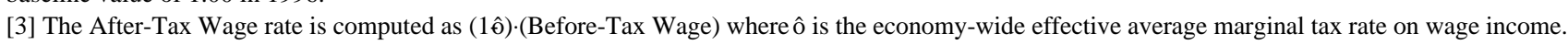

[4] Statutory rate, post evasion. Effective rate is about 0.01 smaller due to evasion. Cash flow on capital income also equals this value.

[5] Percent of National Income. 


\section{Figure 2: "Clean" Income Tax}

\section{Remaining Lifetime Utility}

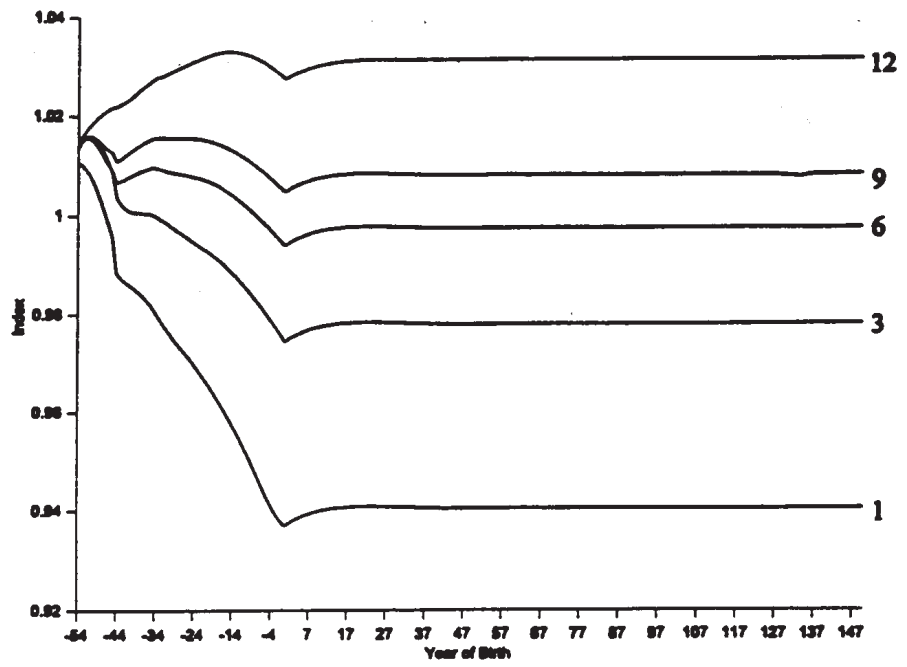


Table 5.

"Clean" Consumption Tax

\begin{tabular}{lll}
$1996 \quad 1997 \quad 1998$ \\
\hline
\end{tabular}

1999

2000

2001

2002

\section{Composition of National Income}

Consumption $^{[1]}+$

Net Investment ${ }^{[1]}+$

0.734

0.053

$0.744 \quad 0.746$

0.750

Government $^{[1]}=$

0.214

0.103

0.110

0.110

0.756

$0.761 \quad 0.765$

2004

2005

2010

2025

2055

National Income ${ }^{[2]}$

0.214

0.214

0.109

0.106

0.104

0.770

0.774

0.778

0.794

0.817

0.823

0.824

Capital Stock, Labor Supply and Total Labor Income

Capital Stock $^{[2]}$

Labor Supply ${ }^{[2]}$

Labor Income ${ }^{[2]}$

$\begin{array}{lll}1.000 & 1.023 & 1.045 \\ 1.000 & 1.084 & 1.076 \\ 1.000 & 1.069 & 1.068\end{array}$

1.074

1.078

$0.214 \quad 0.214$

0.214

0.100

0.098

0.090

0.076

0.072

0.071

1.086

1.088

1.090

0.214

0.214

$0.214 \quad 0.214$

\section{Net Saving Rate}

Net Saving Rate

$0.053 \quad 0.098$

0.103

0.103

0.101

$0.098 \quad 0.096$

0.094

0.09

1.148

1.162

1.216

1.289

$1.311 \quad 1.311$

$\begin{array}{llll}1.072 & 1.069 & 1.067 & 1.065\end{array}$

1.064

1.062

1.061

1.056

1.048

$1.045 \quad 1.045$

Factor Prices: Wage Rate and Interest Rates

Before-Tax Wage ${ }^{[2]} \quad 1.000 \quad 0.986$

After-Tax Wage ${ }^{[3]}$

$1.000 \quad 0.986$

0.993

0.998

$0.817 \quad 0.821$

$1.003 \quad 1.008 \quad 1.012$

Before-Tax Rate of Return

After-Tax Rate of Return

$0.097 \quad 0.102$

$0.080 \quad 0.102$

0.100

0.098

$0.831 \quad 0.836$

1.016

0.841

1.061

1.094

$1.103 \quad 1.106 \quad 1.106$

Unified Government Debt

$\operatorname{Debt}^{[2]}$

$1.000 \quad 1.000$

$\begin{array}{lll}0.100 & 0.098 & 0.096\end{array}$

$0.095 \quad 0.094$

0.093

0.846

0.846

0.092

$0.093 \quad 0.092$

0.090

0.082

$0.069 \quad 0.065 \quad 0.064$

\begin{tabular}{|c|c|c|c|c|c|c|c|c|c|c|}
\hline 1.000 & 1.000 & 1.000 & 1.000 & 1.000 & 1.000 & 1.000 & 1.000 & 1.000 & 1.000 & 0.999 \\
\hline
\end{tabular}

Dynamic Replacement Income Tax Rate and Static Replacement Income Tax Rate

\begin{tabular}{|c|c|c|c|c|c|c|c|c|c|c|c|c|c|c|}
\hline Tax Rate ${ }^{[4]}$ & $\mathrm{n} / \mathrm{a}$ & 0.140 & 0.147 & 0.148 & 0.147 & 0.145 & 0.144 & 0.142 & 0.141 & 0.139 & 0.134 & 0.127 & 0.125 & 0.125 \\
\hline \multicolumn{15}{|c|}{ Tax Revenue and the Endogeous OASDI-HI Payroll Tax } \\
\hline Revenue $^{[5]}$ & 0.239 & 0.233 & 0.242 & 0.244 & 0.244 & 0.244 & 0.244 & 0.243 & 0.243 & 0.242 & 0.240 & 0.238 & 0.238 & 0.238 \\
\hline Payroll Tax Rate & 0.147 & 0.138 & 0.138 & 0.138 & 0.138 & 0.138 & 0.138 & 0.138 & 0.138 & 0.138 & 0.139 & 0.140 & 0.141 & 0.141 \\
\hline \multicolumn{15}{|l|}{ Tobin's O } \\
\hline Normalized Tobin's Q & 1.000 & 0.866 & 0.859 & 0.858 & 0.859 & 0.861 & 0.862 & 0.864 & 0.865 & 0.867 & 0.873 & 0.880 & 0.882 & 0.882 \\
\hline
\end{tabular}

Normalized Tobin's Q

Footnotes:

[1] The components of national income (NI) sum to income (i.e., they are not percentages of NI except, of course, for year 1996 when NI = 1.0).

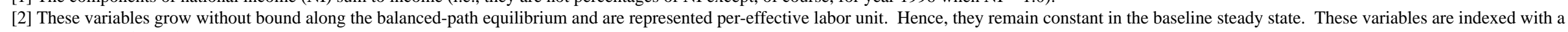
baseline value of 1.00 in 1996

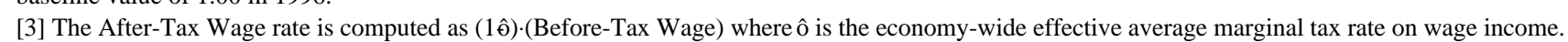

[4] Statutory rate, post evasion. Effective rate is about 0.01 smaller due to evasion. Cash flow on capital income also equals this value.

[5] Percent of National Income. 
Figure 3 "Clean" Consumption Tax

\section{Remaining Lifetime Utility}

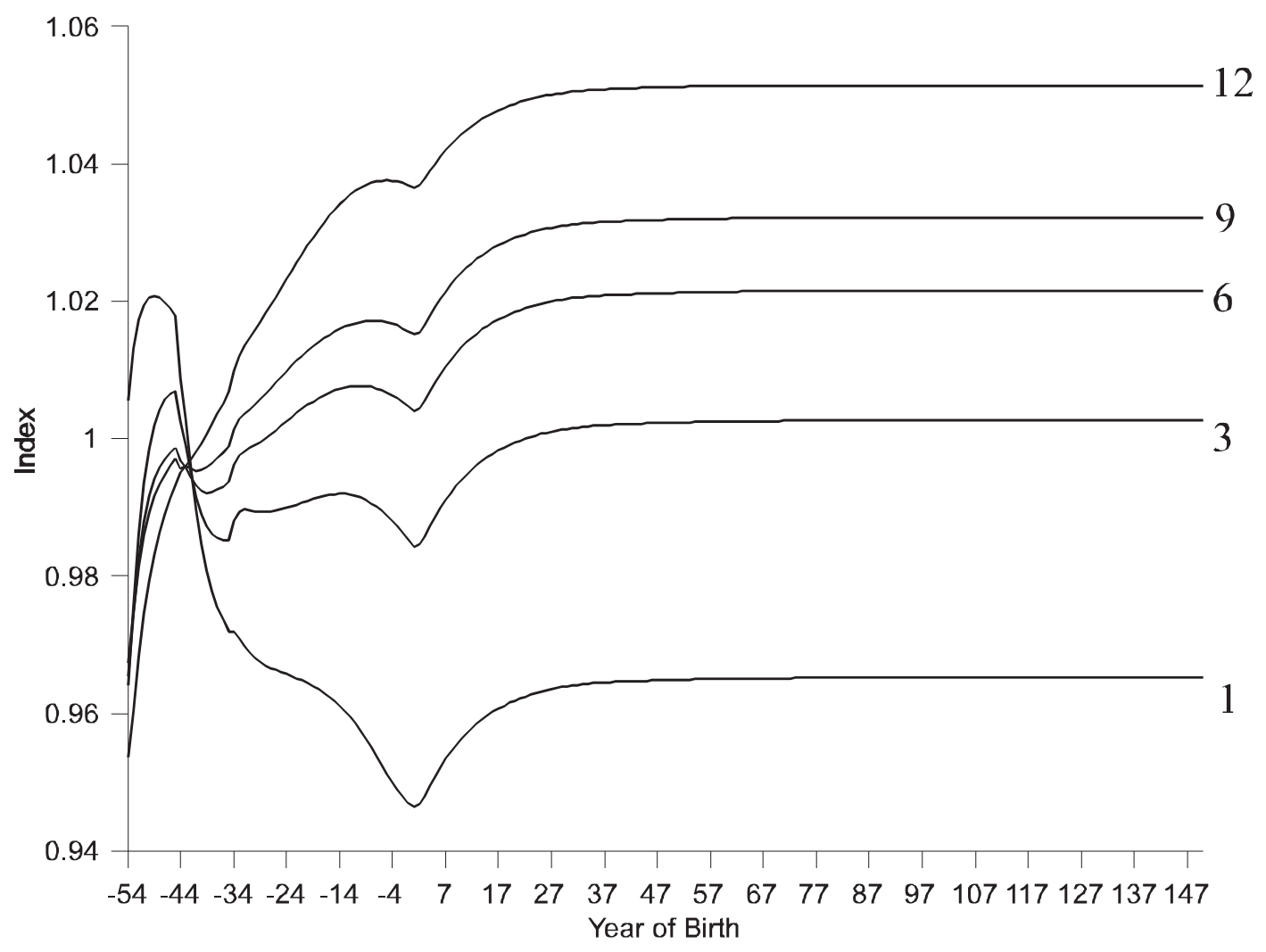




\title{
Table 6.
}

Flat Tax (Standard)

$1996 \quad 1997$

1998

1999

2000

2001

2002

2003

2004

2005

2010

2025

2055

2145

Composition of National Income

Consumption $^{[1]}+$ 0.734

0.724

0.727

Net Investment ${ }^{[1]}+$

0.214

0.086

0.087

Government $^{[1]}=$

National Income ${ }^{[2]}$

$1.000 \quad 1.023$

0.214

0.087

$\begin{array}{ll}0.731 & 0.734\end{array}$

0.737

0.740

0.743

0.745

0.756

0.214

$0.085 \quad 0.085$

0.083

0.082

0.081

0.080

0.077

0.773

0.782

1.028

$1.030 \quad 1.033$

1.035

0.214

0.214

0.214

0.070

1.036

1.038

1.040

0.214

0.214

$0.066 \quad 0.066$

Capital Stock, Labor Supply and Total Labor Income

\section{Capital Stock ${ }^{[2]}$}

Labor Supply ${ }^{[2]}$

Labor Income ${ }^{[2]}$

$1.000 \quad 1.019 \quad 1.033$

$1.000 \quad 1.030 \quad 1.020$

1.045

$1.000 \quad 1.027$

1.023

$1.085 \quad 1.093$

1.101

1.047

1.057

$0.214 \quad 0.214$

$1.061 \quad 1.061$

\section{Net Saving Rate}

Net Saving Rate

\begin{abstract}
$0.053 \quad 0.084$
\end{abstract}
0.085

$\begin{array}{lll}0.083 & 0.082 & 0.081\end{array}$

0.066

0.062

Factor Prices: Wage Rate and Interest Rates

Before-Tax Wage ${ }^{[2]}$

After-Tax Wage ${ }^{[3]}$

$1.000 \quad 0.997$

$1.003 \quad 1.006$

$1.009 \quad 1.012$

1.014

Before-Tax Rate of Return

After-Tax Rate of Return

0.754

0.751

0.753

$\begin{array}{llllllllll}0.757 & 0.761 & 0.764 & 0.767 & 0.770 & 0.773 & 0.785 & 0.803 & 0.811 & 0.813\end{array}$

$\begin{array}{lllllll}1.016 & 1.018 & 1.020 & 1.028 & 1.040 & 1.046 & 1.047\end{array}$

$\begin{array}{lllllllllllllll}0.080 & 0.098 & 0.097 & 0.096 & 0.095 & 0.094 & 0.093 & 0.093 & 0.092 & 0.092 & 0.090 & 0.087 & 0.085 & 0.085\end{array}$

Unified Government Debt

$\operatorname{Debt}^{[2]}$

$1.000 \quad 1.000$

1.0

Dynamic Replacement Income Tax Rate

Tax Rate ${ }^{[4]}$

$\mathrm{n} / \mathrm{a} \quad 0.214$

0.221

(1)

Tax Revenue and the Endogenous OASDI-HI Payroll Tax

\begin{tabular}{|c|c|c|c|c|c|c|c|c|c|c|c|c|c|c|}
\hline Revenue $^{[5]}$ & 0.239 & 0.235 & 0.241 & 0.242 & 0.242 & 0.242 & 0.241 & 0.241 & 0.241 & 0.241 & 0.240 & 0.238 & 0.238 & 0.238 \\
\hline Payroll Tax Rate & 0.147 & 0.144 & 0.145 & 0.145 & 0.144 & 0.144 & 0.144 & 0.144 & 0.144 & 0.144 & 0.143 & 0.143 & 0.143 & 0.143 \\
\hline \multicolumn{15}{|l|}{ Tobin's O } \\
\hline Normalized Tobin's Q & 1.000 & 0.901 & 0.897 & 0.897 & 0.898 & 0.899 & 0.900 & 0.901 & 0.901 & 0.902 & 0.905 & 0.909 & 0.911 & 0.911 \\
\hline
\end{tabular}

Footnotes:

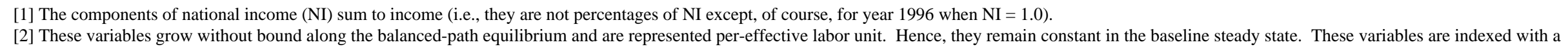
baseline value of 1.00 in 1996 .

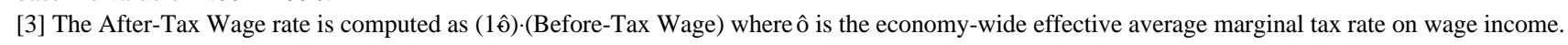

[4] Statutory rate, post evasion. Effective rate is about 0.01 smaller due to evasion. Cash flow on capital income equals half of this value.

[5] Percent of National Income. 
Figure 4 Flat Tax (Standard)

\section{Remaining Lifetime Utility}

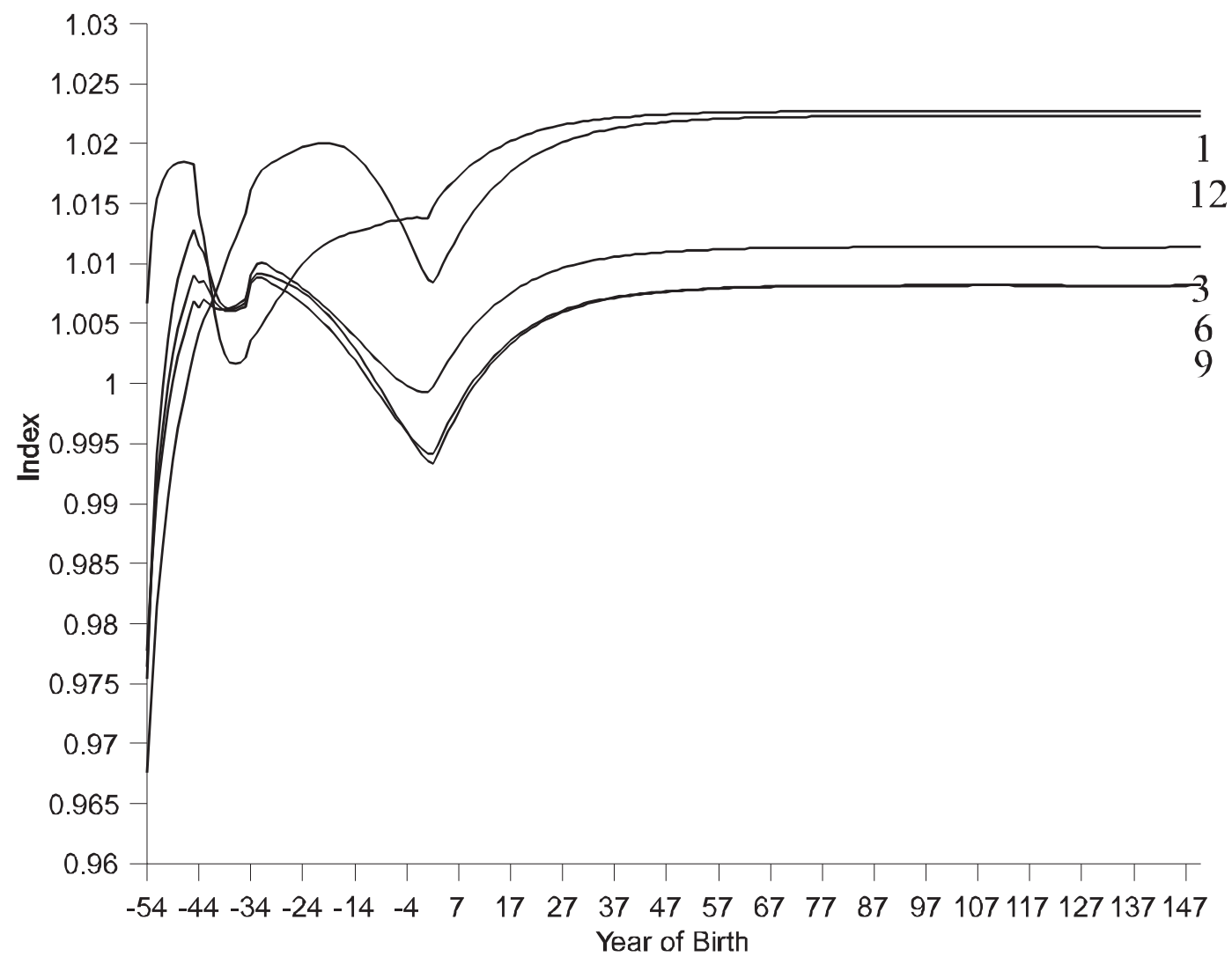




\section{Table $7 . \quad$ Flat Tax (Transition Relief)}

$1996-1997 \quad 1998$

1999

2000

2001

2002

2003

2004

2005

2010

2025

2055

2145

Composition of National Income

Net Investment ${ }^{[1]}+$

$\begin{array}{lll}0.734 & 0.715 & 0.717\end{array}$

$0.053 \quad 0.076$

0.075

$\begin{array}{lll}0.214 & 0.214 & 0.214\end{array}$

Government $^{[1]}=$

$\begin{array}{lll}1.000 & 1.005 & 1.006\end{array}$

$\begin{array}{lll}0.720 & 0.722 & 0.725\end{array}$

0.727

National Income ${ }^{[2]}$

0.074

$0.074 \quad 0.073$

0.072

0.729

0.214

$0.214 \quad 0.214$

0.072

0.072

0.731

1.008

$1.010 \quad 1.012 \quad 1.013$

0.214

0.071

0.733

0.741

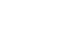

1.015

1.016

0.214

0.068

0.754

0.759

0.761

Capital Stock, Labor Supply and Total Labor Income

Capital Stock

$\begin{array}{lll}1.000 & 1.014 & 1.023\end{array}$

Labor Supply ${ }^{[2]}$

Labor Income ${ }^{[2]}$

$1.000 \quad 1.003 \quad 0.999$

$\begin{array}{llll}1.031 & 1.038 & 1.045 & 1.051\end{array}$

1.057

0.999

$1.000 \quad 1.006$

1.005

1.007

$0.999 \quad 0.999 \quad 0.999$

0.999

1.063

1.018

0.214

0.214

$0.062 \quad 0.061$

\section{Net Saving Rate}

Net Saving Rate

$0.053 \quad 0.076$

0.075

0.074

$0.073 \quad 0.072 \quad 0.071$

0.070

0.069

0.067

0.062

0.060

0.059

Factor Prices: Wage Rate and Interest Rates

Before-Tax Wage ${ }^{[2]}$

After-Tax Wage ${ }^{[3]}$

$1.000 \quad 1.003$

$1.006 \quad 1.008$

$1.010 \quad 1.011$

$\begin{array}{llllll}0.775 & 0.731 & 0.730 & 0.733 & 0.736 & 0.738\end{array}$

1.013

$\begin{array}{lllllll}1.014 & 1.016 & 1.017 & 1.022 & 1.031 & 1.036 & 1.037\end{array}$

Before-Tax Rate of

$0.097 \quad 0.097$

0.096

0.095

$0.095 \quad 0.094$

0.741

0.743

1.016
0.745

1.017
0.747

1.022

$\begin{array}{ll}0.747 & 0.755\end{array}$

0.769

$\begin{array}{lllll}0.743 & 0.745 & 0.747 & 0.755 & 0.769 \\ 0.093 & 0.093 & 0.093 & 0.091 & 0.089\end{array}$

$0.776 \quad 0.778$

Return

After-Tax Rate of Return

$0.080 \quad 0.097$

0.096

0.095

$\begin{array}{lll}0.095 & 0.094 \quad 0.094\end{array}$

0.093

0.093

0.093

0.091

$0.088 \quad 0.087$

\section{Unified Government Debt}

Debt $^{[2]}$

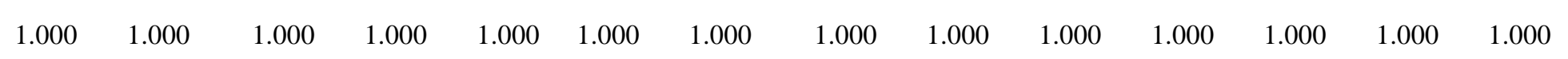

Dynamic Replacement Income Tax Rate

Tax Rate ${ }^{[4]} \quad$ n/a $\quad 0.242$

Tax Revenue and the Endogenous OASDI-HI Payroll Tax

\begin{tabular}{|c|c|c|c|c|c|c|c|c|c|c|c|c|c|c|}
\hline Revenue $^{[5]}$ & 0.239 & 0.238 & 0.240 & 0.240 & 0.240 & 0.240 & 0.240 & 0.239 & 0.239 & 0.239 & 0.239 & 0.238 & 0.237 & 0.237 \\
\hline Payroll Tax Rate & 0.147 & 0.147 & 0.147 & 0.147 & 0.147 & 0.147 & 0.147 & 0.146 & 0.146 & 0.146 & 0.145 & 0.144 & 0.145 & 0.145 \\
\hline Tobin's Q & & & & & & & & & & & & & & \\
\hline Normalized Tobin's Q & 1.000 & 0.950 & 0.949 & 0.949 & 0.950 & 0.950 & 0.950 & 0.951 & 0.951 & 0.951 & 0.952 & 0.954 & 0.955 & 0.955 \\
\hline
\end{tabular}

Footnotes:

[1] The components of national income (NI) sum to income (i.e., they are not percentages of NI except, of course, for year 1996 when NI = 1.0).

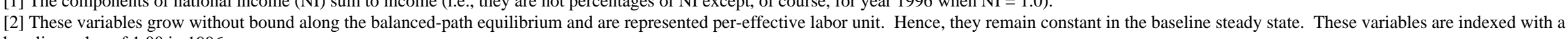
baseline value of 1.00 in 1996.

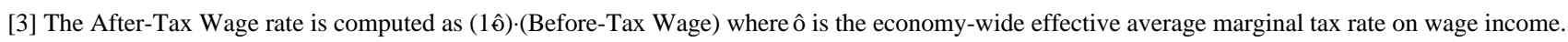

[4] Statutory rate, post evasion. Effective rate is about 0.01 smaller due to evasion. Cash flow on capital income equals one-fourth of this value. [5] Percent of National Income. 
Figure 5 Flat Tax (Transition Relief)

\section{Remaining Lifetime Utility}

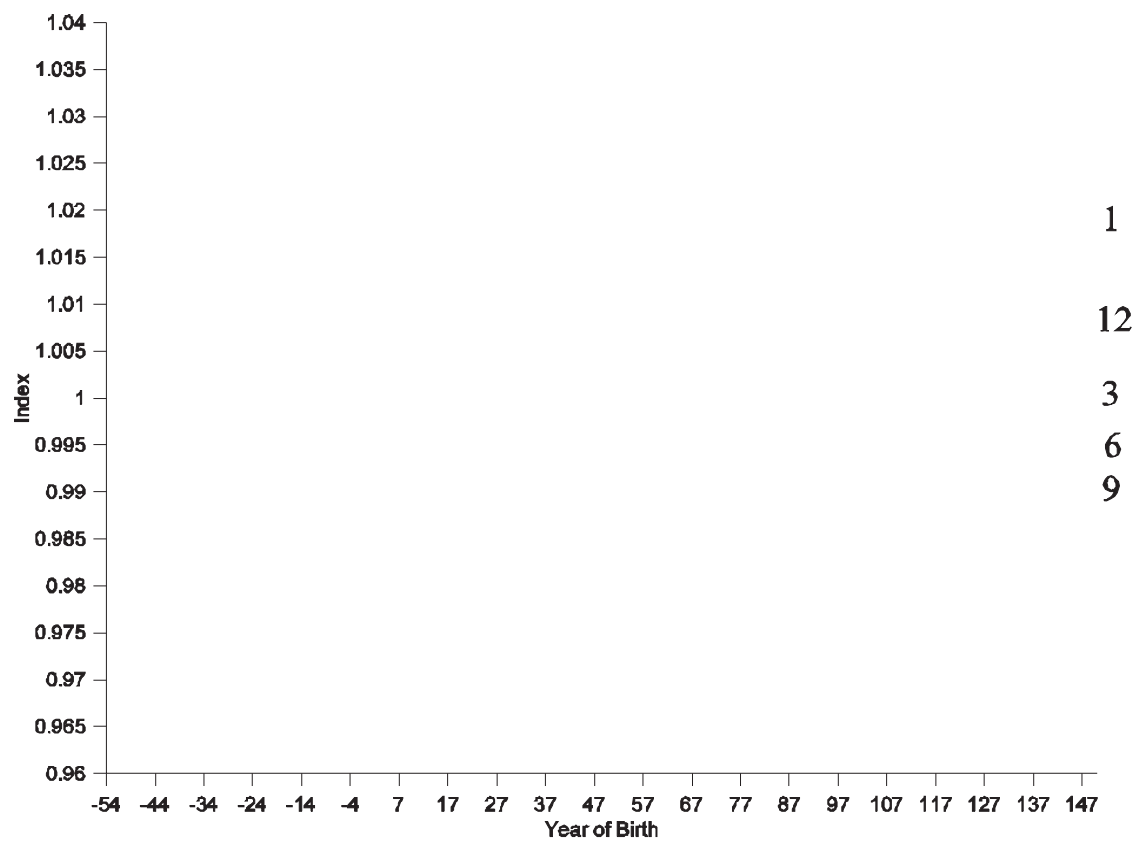




\section{Table 8. $\quad \mathrm{X}$ Tax}

1996

\section{Composition of National Income}

Consumption $^{[1]}+$

Net Investment ${ }^{[1]}+$

0.734

1997

1998

1999

2000

2001

2002

2003

2004

2005

2010

2025

2055

Government ${ }^{[1]}$

National Income ${ }^{[2]}$

0.053

$\begin{array}{lll}0.714 & 0.719 & 0.723\end{array}$

$\begin{array}{lll}0.726 & 0.730 & 0.733\end{array}$

0.736

0.739

0.742

0.753

0.774

0.786

0.789

$0.214 \quad 0.214$

0.092

0.091

$0.090 \quad 0.090$

0.088

0.087

0.087

0.084

0.078

0.074

0.073

$1.000 \quad 1.021$

1.024

0.214
1.027

$\begin{array}{lll}0.214 & 0.214 & 0.214\end{array}$

0.214

0.214

0.214

0.214

0.214

$0.214 \quad 0.214$

Capital Stock, Labor Supply and Total Labor Income

Capital Stock ${ }^{[2]}$

Labor Supply ${ }^{[2]}$

$1.000 \quad 1.031 \quad 1.043$

$1.000-1.012-1.012$

1.055

$1.066 \quad 1.076 \quad 1.086$

1.096

1.105

1.114

1.151

1.220

1.262

1.272

Labor Income ${ }^{[2]}$

$1.000 \quad 1.017$

1.020

1.012

$1.013 \quad 1.013$

1.013

1.013

1.013

1.014

1.014

1.013

$1.012 \quad 1.012$

\section{Net Saving Rate}

Net Saving Rate

$0.053 \quad 0.091$

0.089

$0.088 \quad 0.087 \quad 0.086$

0.085

0.084

0.083

0.080

0.073

0.069

0.068

Factor Prices: Wage Rate and Interest Rates

Before-Tax Wage ${ }^{[2]}$

$1.000 \quad 1.005$

After-Tax Wage ${ }^{[3]}$

$0.775 \quad 0.766$

1.008

$\begin{array}{llll}1.010 & 1.013 & 1.015 & 1.018\end{array}$

1.020

1.022

1.024

1.032

1.047

1.057

1.059

Before-Tax Rate of

$0.097 \quad 0.096$

0.771

0.775

$0.780 \quad 0.784$

0.788

0.791

0.795

0.799

0.812

0.836

0.851

0.855

Return

After-Tax Rate of Return

$0.080 \quad 0.096$

0.095

0.094

$0.094 \quad 0.093-0.092$

0.09

0.091

0.091

0.088

0.085

0.082

0.082

Unified Government Debt

$\operatorname{Debt}^{[2]}$

$1.000 \quad 1.000$

1.000

1.000

$1.000 \quad 1.000$

1.000

1.000

0.088

$\begin{array}{lll}0.085 & 0.082 & 0.082\end{array}$

Dynamic Replacement Income Tax Rate

Tax Rate ${ }^{[4]}$

$0.200 \quad 0.198 \quad 0.196$

0.194

0.192

0.163

Tax Revenue and the Endogeous OASDI-HI Payroll Tax

Revenue $^{[5]}$

Payroll Tax Rate

$0.147 \quad 0.145$

0.243
0.144

0.243

$0.243 \quad 0.243$

0.242

0.242

0.242

0.242

0.241

0.239

0.239

0.238

Tobin's Q

Normalized Tobin's Q

$1.000 \quad 0.856$

0.856

0.856

$\begin{array}{lll}0.856 & 0.856 & 0.856\end{array}$

0.856

0.856

0.856

0.856

0.856

0.856

0.856

[1] The components of national income (NI) sum to income (i.e., they are not percentages of NI except, of course, for year 1996 when NI = 1.0).

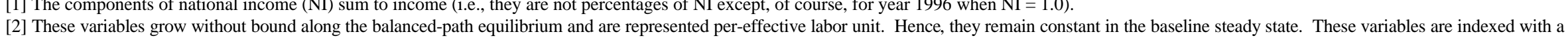
baseline value of 1.00 in 1996 .

[3] The After-Tax Wage rate is computed as (1)̂े).(Before-Tax Wage) where ô is the economy-wide effective average marginal tax rate on wage income.

[4] Not proportional for the $\mathrm{X}$ tax. The value shown equals the economy-wide effective average marginal tax rate on wage income which is also reported in this table for the initial steady

state. Statutory rate, post evasion. Effective rate is about 0.01 smaller due to evasion. Cash flow on capital income equals 0.15 . [5] Percent of National Income. 
Figure $6 \times$ Tax

Remaining Lifetime Utility

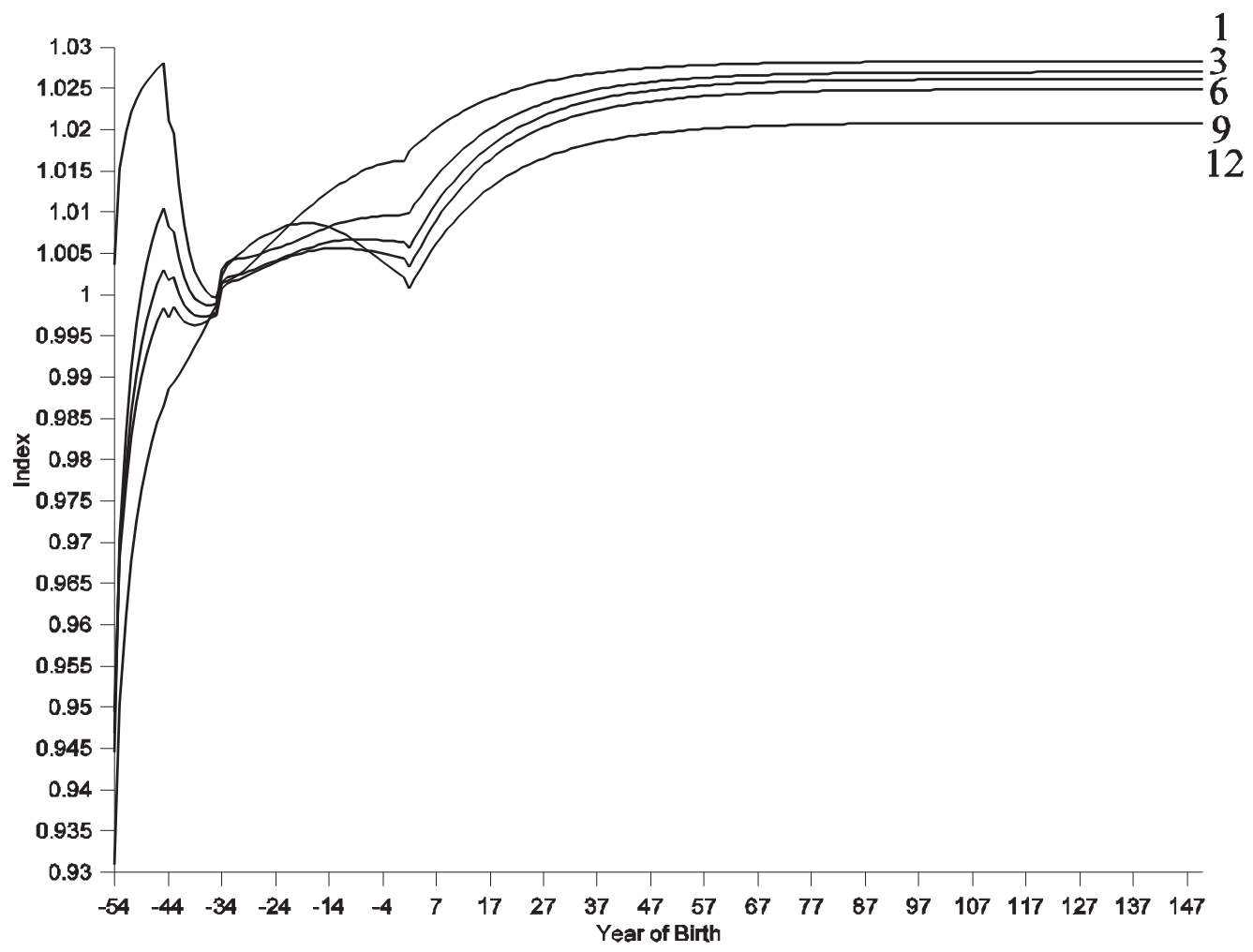




\begin{tabular}{|c|c|c|c|c|c|}
\hline \multirow{2}{*}{$\begin{array}{l}\text { Related } \\
\text { Table/ } \\
\text { Figure }\end{array}$} & \multicolumn{4}{|c|}{ Parameter Changed } & \multirow{2}{*}{$\begin{array}{l}\text { Calibration } \\
\text { Parameter }^{[1]}\end{array}$} \\
\hline & $\begin{array}{l}\text { Paramet } \\
\text { er }\end{array}$ & From & To & Purpose & \\
\hline $10 / 7$ & $\phi$ & 0.00 & 10.00 & Introduce adjustment costs & $\ddot{a}$ \\
\hline $11 / 8$ & $\tilde{\mathrm{n}}$ & 0.80 & 0.40 & Reduce the intratemporal elasticity & á \\
\hline $12 / 9$ & $\tilde{a}$ & 0.25 & 0.10 & Reduce the intertemporal elasticity & $\ddot{a}$ \\
\hline
\end{tabular}




\begin{tabular}{|c|c|c|c|c|c|c|c|c|c|c|c|c|c|c|}
\hline & 1996 & 1997 & 1998 & 1999 & 2000 & 2001 & 2002 & 2003 & 2004 & 2005 & 2010 & 2025 & 2055 & 2145 \\
\hline \multicolumn{15}{|c|}{ Composition of National Income } \\
\hline Consumption $^{[1]}+$ & 0.733 & 0.729 & 0.729 & 0.730 & 0.732 & 0.733 & 0.734 & 0.736 & 0.737 & 0.738 & 0.744 & 0.755 & 0.765 & 0.770 \\
\hline Net Investment ${ }^{[1]}+$ & 0.050 & 0.062 & 0.063 & 0.064 & 0.064 & 0.063 & 0.063 & 0.063 & 0.063 & 0.063 & 0.062 & 0.061 & 0.060 & 0.059 \\
\hline Government $^{[1]}=$ & 0.218 & 0.218 & 0.218 & 0.218 & 0.218 & 0.218 & 0.218 & 0.218 & 0.218 & 0.218 & 0.218 & 0.218 & 0.218 & 0.218 \\
\hline National Income ${ }^{[2]}$ & 1.000 & 1.009 & 1.010 & 1.012 & 1.013 & 1.014 & 1.016 & 1.017 & 1.018 & 1.019 & 1.024 & 1.034 & 1.042 & 1.047 \\
\hline \multicolumn{15}{|c|}{ Capital Stock, Labor Supplv and Total Labor Income } \\
\hline Capital Stock $^{[2]}$ & 1.000 & 1.006 & 1.011 & 1.016 & 1.021 & 1.025 & 1.030 & 1.034 & 1.038 & 1.042 & 1.059 & 1.096 & 1.131 & 1.150 \\
\hline Labor Supply ${ }^{[2]}$ & 1.000 & 1.016 & 1.014 & 1.013 & 1.013 & 1.012 & 1.013 & 1.013 & 1.013 & 1.013 & 1.013 & 1.013 & 1.013 & 1.013 \\
\hline Labor Income $^{[2]}$ & 1.000 & 1.013 & 1.013 & 1.014 & 1.015 & 1.015 & 1.017 & 1.018 & 1.019 & 1.020 & 1.024 & 1.034 & 1.041 & 1.045 \\
\hline \multicolumn{15}{|l|}{ Net Saving Rate } \\
\hline Net Saving Rate & 0.050 & 0.062 & 0.063 & 0.063 & 0.063 & 0.063 & 0.063 & 0.062 & 0.062 & 0.062 & 0.061 & 0.059 & 0.057 & 0.056 \\
\hline \multicolumn{15}{|c|}{ Factor Prices: Wage Rate and Interest Rates } \\
\hline Before-Tax Wage ${ }^{[2]}$ & 1.000 & 0.997 & 0.999 & 1.001 & 1.002 & 1.003 & 1.004 & 1.005 & 1.006 & 1.007 & 1.011 & 1.020 & 1.028 & 1.032 \\
\hline After-Tax Wage $\mathrm{e}^{[3]}$ & 0.775 & 0.754 & 0.753 & 0.754 & 0.755 & 0.756 & 0.758 & 0.759 & 0.760 & 0.762 & 0.767 & 0.780 & 0.791 & 0.796 \\
\hline Before-Tax Rate of & 0.083 & 0.076 & 0.078 & 0.079 & 0.079 & 0.079 & 0.079 & 0.079 & 0.079 & 0.079 & 0.078 & 0.078 & 0.077 & 0.080 \\
\hline \multicolumn{15}{|l|}{ Return } \\
\hline After-Tax Rate of Return & 0.059 & 0.062 & 0.063 & 0.063 & 0.063 & 0.063 & 0.064 & 0.064 & 0.064 & 0.064 & 0.064 & 0.064 & 0.063 & 0.066 \\
\hline \multicolumn{15}{|l|}{ Unified Government Debt } \\
\hline $\operatorname{Debt}^{[2]}$ & 1.000 & 1.000 & 1.000 & 1.000 & 1.000 & 1.000 & 1.000 & 1.000 & 1.001 & 1.000 & 1.000 & 1.000 & 0.999 & 1.000 \\
\hline
\end{tabular}




\section{Dynamic Replacement Income Tax Rate}

\section{Tax Rate ${ }^{[4]}$ \\ $\mathrm{n} / \mathrm{a}$}

0.214

$0.217 \quad 0.217$

$0.217 \quad 0.216$

0.215

0.215

0.214

0.214

0.211

0.206

0.201

0.199

Tax Revenue and the Endogenous OASDI-HI Pavroll Tax

Revenue $^{[5]}$

0.237

0.239

0.240

0.240

0.240

0.240

0.240

$0.240 \quad 0.239 \quad 0.239$

0.238

Payroll Tax Rate

$0.146 \quad 0.145$

0.146

0.145

0.145

0.145

0.145

0.145

0.145

0.145

0.145

0.144

0.144

0.144

Tobin's Q

Normalized Tobin's Q

$\begin{array}{llll}1.000 & 0.964 & 0.965 & 0.965\end{array}$

$0.965 \quad 0.964 \quad 0.963$

0.962

0.962

0.961

0.958

0.951

0.944

0.941

Footnotes:

[1] The components of national income (NI) sum to income (i.e., they are not percentages of NI except, of course, for year 1996 when NI = 1.0).

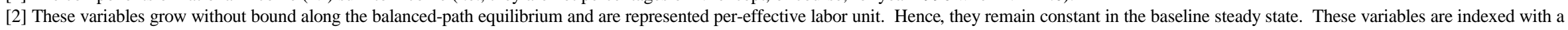
baseline value of 1.00 in 1996.

[3] The After-Tax Wage rate is computed as (10̂).(Before-Tax Wage) where ô is the economy-wide effective average marginal tax rate on wage income.

[4] Statutory rate, post evasion. Effective rate is about 0.01 smaller due to evasion. Cash flow on capital income equals half of this value.

[5] Percent of National Income. 
Figure 7 Flat Tax (Standard) with Adjustment Costs

\section{Remaining Lifetime Utility}

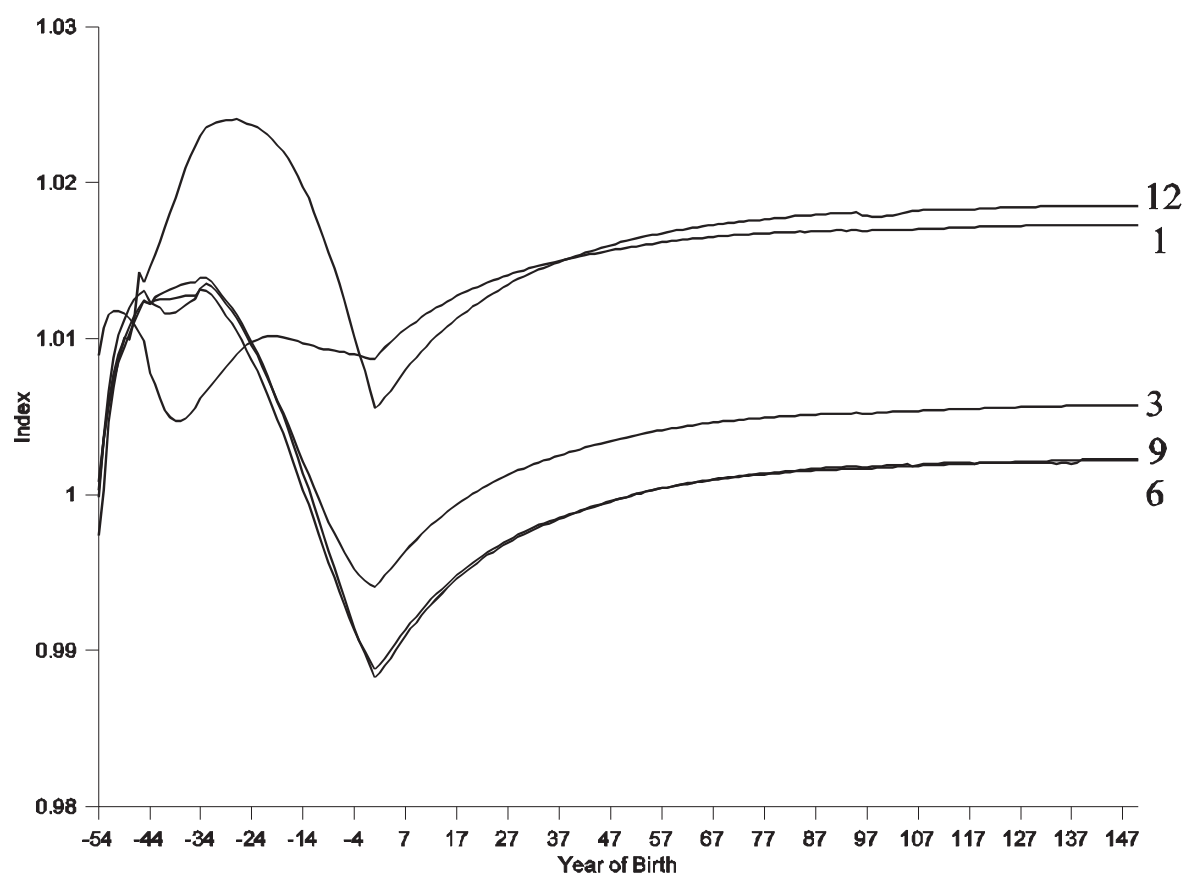


Table 11.

Flat Tax (Standard): Low Intratemporal Substitution Elasticity $(\tilde{\mathrm{n}}=0.40)$

\begin{tabular}{|c|c|c|c|c|c|c|c|c|c|c|c|c|c|}
\hline 1996 & 1997 & 1998 & 1999 & 2000 & 2001 & 2002 & 2003 & 2004 & 2005 & 2010 & 2025 & 2055 & 2145 \\
\hline Income & & & & & & & & & & & & & \\
\hline 0.738 & 0.726 & 0.728 & 0.730 & 0.733 & 0.735 & 0.737 & 0.739 & 0.741 & 0.743 & 0.750 & 0.761 & 0.765 & 0.766 \\
\hline 0.053 & 0.086 & 0.088 & 0.087 & 0.085 & 0.084 & 0.083 & 0.081 & 0.080 & 0.079 & 0.075 & 0.068 & 0.065 & 0.065 \\
\hline 0.210 & 0.210 & 0.210 & 0.210 & 0.210 & 0.210 & 0.210 & 0.210 & 0.210 & 0.210 & 0.210 & 0.210 & 0.210 & 0.210 \\
\hline 1.000 & 1.022 & 1.025 & 1.027 & 1.028 & 1.029 & 1.030 & 1.030 & 1.031 & 1.032 & 1.035 & 1.038 & 1.040 & 1.040 \\
\hline
\end{tabular}

Composition of National Income

Consumption $^{[1]}+$

and Total Labor Income

Capital Stock, Labor Supply and Total Labor Income
Capital Stock

\begin{tabular}{|c|c|}
\hline 1.000 & 1.018 \\
\hline
\end{tabular}

1.044

$1.055 \quad 1.066 \quad 1.075$

Labor Supply ${ }^{[2]}$

$1.000 \quad 1.029 \quad 1.021$

1.017

$1.015 \quad 1.013$

1.011

1.084

1.09

1.0

$1.000 \quad 1.026$

1.024

1.024

$1.025 \quad 1.026 \quad 1.026$

1.009

1.008

1.007

1.130

1.174

1.190

1.196

Labor Income ${ }^{[2]}$

Net Saving Rate

Net Saving Rate

$0.053 \quad 0.085$

0.086

0.084

$0.083 \quad 0.082 \quad 0.080$

0.079

0.078

0.077

0.072

0.065

$0.063 \quad 0.063$

Factor Prices: Wage Rate and Interest Rates

Before-Tax Wage ${ }^{[2]}$

$1.000 \quad 0.997$

1.003

After-Tax Wage ${ }^{[3]}$

$0.775 \quad 0.755$

0.753

1.007

$1.010-1.013$

1.015

1.018

1.020

1.022

1.031

$1.043 \quad 1.047 \quad 1.048$

Before-Tax Rate of

$0.097 \quad 0.098$

0.096

0.755

$\begin{array}{lll}0.759 & 0.762 \quad 0.765\end{array}$

0.769

0.771

0.774

0.785

$\begin{array}{lll}0.801 & 0.806 \quad 0.807\end{array}$

Return

After-Tax Rate of Return

$0.080 \quad 0.098$

0.096

0.095

$\begin{array}{lll}0.094 & 0.093 \quad 0.093\end{array}$

0.092

0.091

0.091

0.089

0.085

$0.084 \quad 0.084$

Unified Government Debt

$\operatorname{Debt}^{[2]}$

$\begin{array}{llllll}1.000 & 1.000 & 1.000 & 1.000 & 1.000 & 1.000\end{array}$

1.000

1.000

1.000

1.000

$1.000 \quad 1.000$

1.000 


\section{Dynamic Replacement Income Tax Rate}

\section{Tax Rate ${ }^{[4]}$ \\ $\mathrm{n} / \mathrm{a}$}

0.213

0.220

0.220

$0.219 \quad 0.218$

0.216

0.215

0.214

0.213

0.209

0.203

0.201

0.200

Tax Revenue and the Endogenous OASDI-HI Pavroll Tax

Revenue $^{[5]}$

0.231

0.236

0.238

$\begin{array}{lll}0.238 & 0.237 & 0.237\end{array}$

0.237

0.236

0.236

0.235

0.234

0.234

Payroll Tax Rate

$0.151 \quad 0.148$

0.148

0.148

0.148

0.148

0.148

0.148

0.148

0.148

0.148

0.149

0.148

0.148

\section{Tobin's Q}

Normalized Tobin's Q

$1.000 \quad 0.902$

0.898

0.898

$\begin{array}{lll}0.898 & 0.899 & 0.900\end{array}$

0.900

0.901

0.902

0.904

0.907

0.908

0.908

Footnotes:

[1] The components of national income (NI) sum to income (i.e., they are not percentages of NI except, of course, for year 1996 when NI = 1.0).

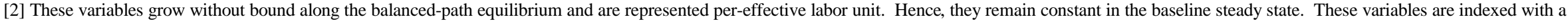
baseline value of 1.00 in 1996.

[3] The After-Tax Wage rate is computed as (10̂).(Before-Tax Wage) where ô is the economy-wide effective average marginal tax rate on wage income.

[4] Statutory rate, post evasion. Effective rate is about 0.01 smaller due to evasion. Cash flow on capital income equals half of this value.

[5] Percent of National Income. 
Figure 8 Flat Tax

Low Intratemporal Substitution Elasticity $(\rho=0.40)$

Remaining Lifetime Utility

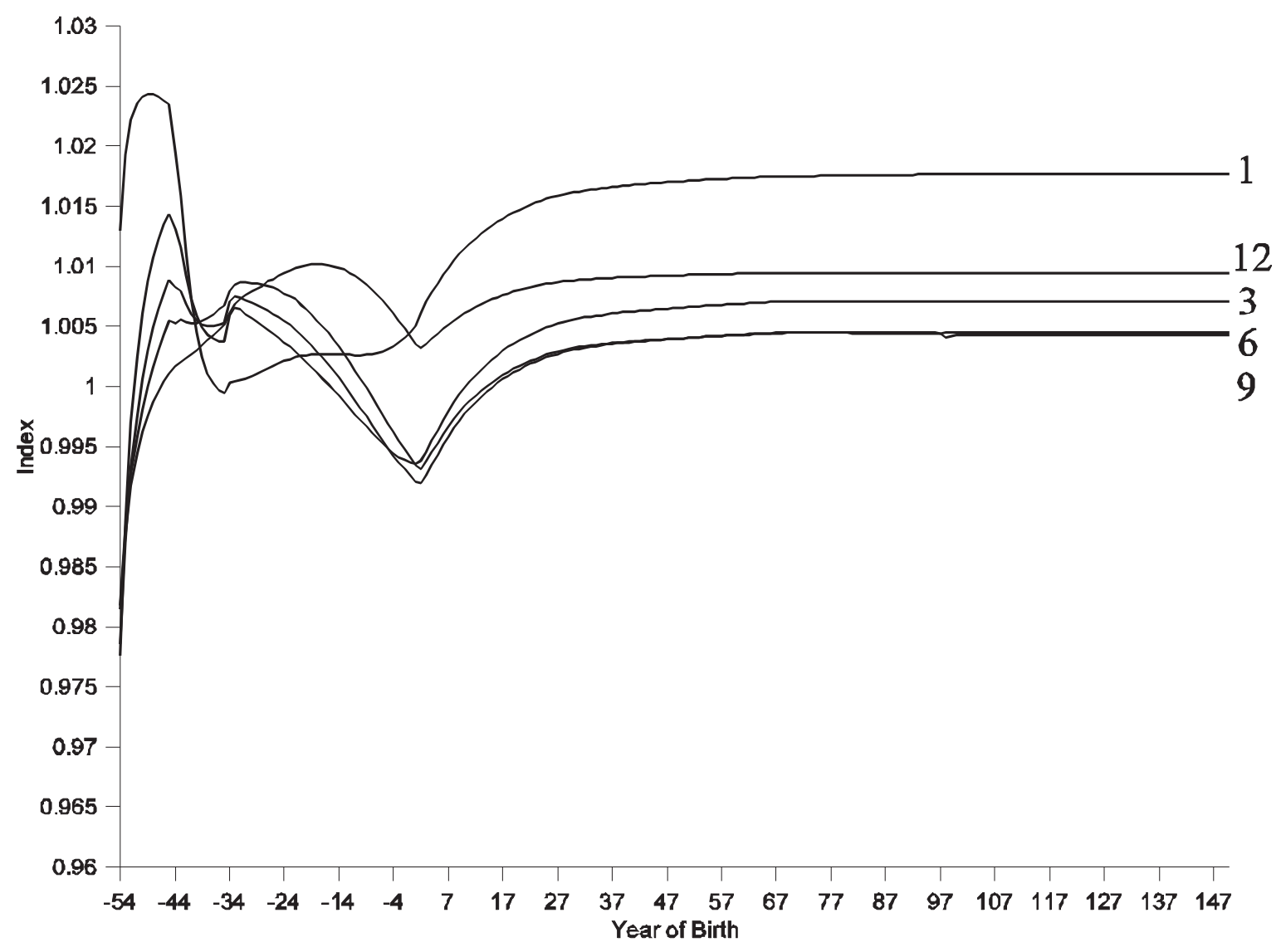


Table 12.

Flat Tax (Standard): Low Intertemporal Substitution Elasticity ( $\tilde{a}=0.10)$

\begin{tabular}{ccccccccccccccccccc}
1996 & 1997 & 1998 & 1999 & 2000 & 2001 & 2002 & 2003 & 2004 & 2005 & 2010 & 2025 & 2055 & 2145 \\
\hline $\begin{array}{c}\text { Income } \\
0.734\end{array}$ & 0.729 & 0.728 & 0.729 & 0.730 & 0.732 & 0.733 & 0.734 & 0.735 & 0.736 & 0.741 & 0.751 & 0.755 & 0.758 \\
0.053 & 0.065 & 0.068 & 0.068 & 0.067 & 0.067 & 0.067 & 0.066 & 0.066 & 0.066 & 0.064 & 0.062 & 0.061 & 0.061 \\
0.214 & 0.214 & 0.214 & 0.214 & 0.214 & 0.214 & 0.214 & 0.214 & 0.214 & 0.214 & 0.214 & 0.214 & 0.214 & 0.214 \\
1.000 & 1.009 & 1.009 & 1.010 & 1.011 & 1.012 & 1.013 & 1.014 & 1.015 & 1.016 & 1.020 & 1.026 & 1.030 & 1.032
\end{tabular}

Composition of National Income

Consumption $^{[1]}+$

and Total Labor Income

Capital Stock, Labor Supply and Total Labor Income
Capital Stock

$1.000 \quad 1.010 \quad 1.016$

1.021

1.025

$1.000 \quad 1.013 \quad 1.005$

1.003

0.002

Labor Supply ${ }^{[2]}$

1.000

$1.012 \quad 1.008$

$\begin{array}{llll}1.007 & 1.008 & 1.009 & 1.010\end{array}$

1.036

1.040

Labor Income ${ }^{[2]}$

\section{Net Saving Rate}

Net Saving Rate

$0.053 \quad 0.065$

0.067

0.067

$0.067 \quad 0.066 \quad 0.066$

0.065

0.065

0.065

0.063

$0.061 \quad 0.059 \quad 0.059$

Factor Prices: Wage Rate and Interest Rates

Before-Tax Wage ${ }^{[2]} \quad 1.000 \quad 0.999$

After-Tax Wage ${ }^{[3]}$

$0.775 \quad 0.756$

1.003

Before-Tax Rate of

$0.097 \quad 0.097$

$1.003 \quad 1.004$

1.006

0.751

0.750

$0.752 \quad 0.753$

0.096

0.096

$0.096 \quad 0.095$

1.007

1.008

1.009

Return

After-Tax Rate of Return

$0.080 \quad 0.097$

0.096

0.096

$\begin{array}{lll}0.096 & 0.095 & 0.095\end{array}$

0.095

0.095

0.094

0.094

0.092

0.091

0.091

Unified Government Debt

$\operatorname{Debt}^{[2]}$

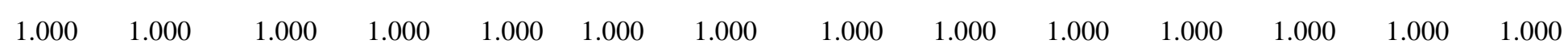




\section{Dynamic Replacement Income Tax Rate}

\section{Tax Rate ${ }^{[4]}$ \\ $\mathrm{n} / \mathrm{a}$}

0.213

0.221

0.223

0.223

0.222

0.221

0.221

0.220

0.219

0.217

0.212

0.209

0.208

Tax Revenue and the Endogenous OASDI-HI Pavroll Tax

Revenue $^{[5]}$

0.234

0.240

0.242

$\begin{array}{lll}0.242 & 0.242 & 0.242\end{array}$

0.242

0.242

0.242

0.241

0.241

0.240

0.240

Payroll Tax Rate

$0.147 \quad 0.146$

0.146

0.146

0.146

0.146

0.146

0.146

0.146

0.146

0.146

0.145

0.145

0.145

\section{Tobin's Q}

Normalized Tobin's Q

$1.000-0.902$

0.897

0.897

$0.897 \quad 0.897$

0.897

0.898

0.898

0.898

0.900

0.902

0.904

0.904

Footnotes:

[1] The components of national income (NI) sum to income (i.e., they are not percentages of NI except, of course, for year 1996 when NI = 1.0)

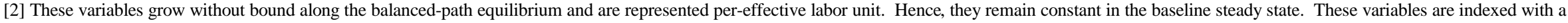
baseline value of 1.00 in 1996.

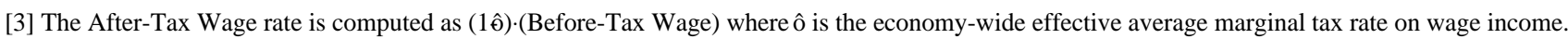

[4] Statutory rate, post evasion. Effective rate is about 0.01 smaller due to evasion. Cash flow on capital income equals half of this value.

[5] Percent of National Income. 


\section{Figure 9 Flat Tax (Standard)}

Low Intertemporal Substitution Elasticity $(\gamma=0.10)$

\section{Remaining Lifetime Utility}

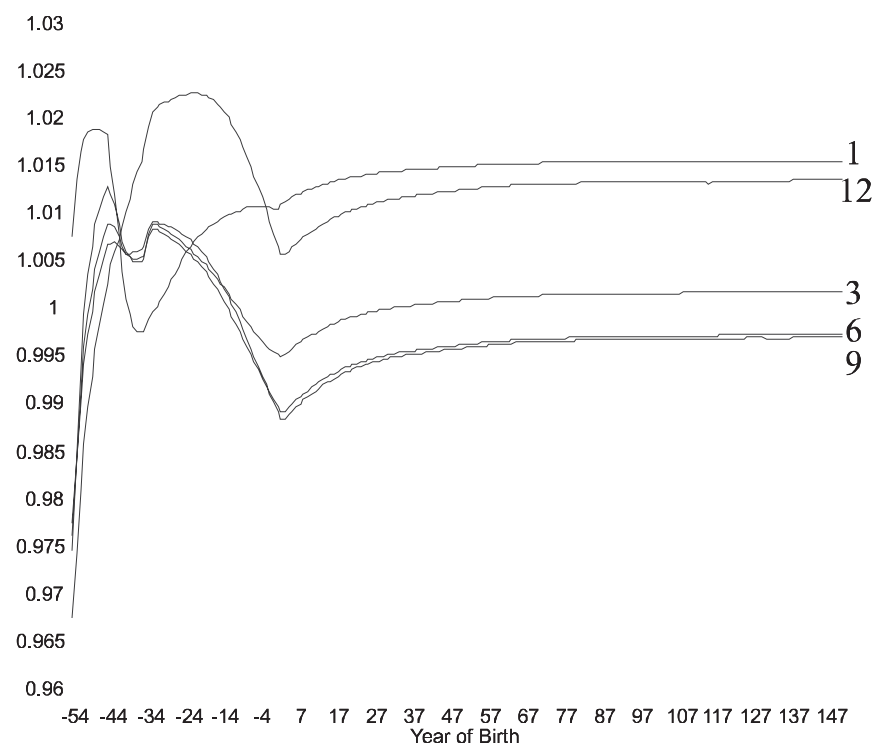




\section{Appendix: Calculation of Earnings-Ability Profiles}

Our earnings-ability profiles are based on the individual files of the University of Michigan's Panel Study of Income Dynamics from 1976-1988. These calculations generally follow those of Fullerton and Rogers (1993).

The sample utilized contains 9335 observations on 891 individuals. Excluded were individuals with imputed real hourly earnings of less than one dollar and those with clear inconsistencies in levels of educational attainment over the time period. This sample differs from that used by Fullerton and Rogers, who (1) aggregate individual observations into household observations and (2) consider only households with stable marital histories.

The following procedure was used to obtain the profiles shown in Figure 1.

(i) First stage regressions were run on the entire data set using a common set of explanatory variables. The specification is identical to that used by Fullerton and Rogers except a

$$
\begin{aligned}
\oiint_{i t}= & \alpha_{i}+\alpha_{1} B Y_{i}+\alpha_{2} A_{i t}+\alpha_{3} A_{i t}^{2}+\alpha_{4} A_{i t}^{3}+\alpha_{5} A_{i t} E_{i t}+ \\
& \sum_{h=1}^{3} \alpha_{i+5} A_{i t} D_{i t}^{h}+\alpha_{9} A_{i t}^{2} E_{i t}+\sum_{h=1}^{3} \alpha_{i+9} A_{i t}^{2} D_{i t}^{h}+\varepsilon_{i t}
\end{aligned}
$$

birth-year variable, which is added to control for age-cohort effects. It is given by where

$$
\begin{aligned}
& \$_{i s}=\text { the log of the real hourly wage for person } i \text { in time } t, \\
& \text {a a }_{i}=\text { fixed effect for person } i, \\
& Y_{i}=\text { the birth year of person } i, \\
& A_{i t}=\text { the age of person } i \text { in time } \mathrm{t}, \\
& E_{i t}=\text { the education level (in years) of person } i \text { in time } t, \\
& D_{i t}=\text { dummy variable for the marital status of person } i \text { in time } t,
\end{aligned}
$$


$D_{i t}{ }^{2}=$ dummy variable for the (constant) race of person $i$,

$D_{i t}{ }^{3}=$ dummy variable for the (constant) sex of person $i$.

The resulting coefficient estimates are reported in Table A1.

(ii) The coefficient estimates obtained from step (i) were used to construct simulated life-cycle wage profiles for each individual from age 21 through 80 . Unlike Fullerton and Rogers, we do not splice wage observations from the PSID with predicted values in generating the profiles. Instead we simply use predicted values for all wage observations. In constructing the profiles we set education to the highest reported level and assume that marital status is constant and equal to married if the individual is married at any time over the PSID sample period.

(iii) Lifetime wage income (LI) levels are imputed from the profiles generated in step (ii)

$$
L I_{i}=\sum_{s=21}^{80}(1+r)^{(s 21)}\left(\$_{i s} \bullet 4000\right)
$$

according to the formula

where the discount rate $r$ is set to 8 percent, $\mathbb{\Phi}_{i s}$ is the predicted wage of the individual at age $s$, and 4000 is the potential full-time endowment of work hours. This calculation follows Fullerton and Rogers, except for the choice of $r$.

All observations were next sorted in ascending order of lifetime wage income, and divided into the twelve groups described in the text. Following the text and letting $\tilde{a}^{j}$ be the fraction of the population in group $j$, our division yields $\tilde{a}^{j}=0.02$ for $j=1$ and $12, \tilde{a}^{j}=0.08$ for $j$ $=2$ and 11 , and $\tilde{\mathrm{a}}^{j}=0.1$ for $j=3$ through 10 .

(iv) Finally, regressions of the predicted wage observations on a common group intercept

$$
\oiint_{i s}^{j}=a_{0}^{j}+a_{1}^{j} A_{i s}^{j}+a_{2}\left(A_{i s}^{j}\right)^{2}+a_{3}^{j}\left(A_{i s}^{j}\right)^{3}+\zeta_{i s}^{j} .
$$

and a cubic in age were run for each group:

The estimated coefficients from these regressions are reported in Table A2. Figure 1's profiles are 
based on these estimates adjusted for annual efficiency growth of one percent.

Table A1: PSID Regression Results

\begin{tabular}{|c|c|c|}
\hline Variable & Coefficient & T statistic \\
\hline Birth Year (BY) & -0.0005 & 1.47 \\
\hline Age $(A)$ & 0.0883 & 3.46 \\
\hline Age-Squared & -0.0016 & 3.20 \\
\hline Age-Cubed & $6.66 \mathrm{E}-6$ & 2.07 \\
\hline Age $x$ Education $\left(\mathrm{A} \mathrm{D}^{1}\right)$ & -0.0009 & 2.02 \\
\hline Age x Marital Status $\left(\mathrm{A} \mathrm{D}^{2}\right)$ & 0.0081 & 3.37 \\
\hline Age $x$ Race $\left(\mathrm{A} \mathrm{D}^{3}\right)$ & 0.0119 & 2.81 \\
\hline $\operatorname{Age} x \operatorname{Sex}\left(\mathrm{A} \mathrm{D}^{4}\right)$ & 0.0339 & 1.69 \\
\hline Age-Squared $x$ Education $\left((A)^{2} D^{1}\right)$ & $2.16 \mathrm{E}-5$ & 3.30 \\
\hline Age-Squared x Marital Status $\left((A)^{2} D^{2}\right)$ & -0.0001 & 2.84 \\
\hline Age-Squared $x$ Race $\left((A)^{2} D^{3}\right)$ & -0.0002 & 2.70 \\
\hline Age-Squared x Sex $\left((A)^{2} D^{4}\right)$ & -0.0004 & 2.00 \\
\hline Adjusted $\mathrm{R}^{2}$ & 0.9779 & - \\
\hline
\end{tabular}


Table A2: Estimated Coefficients for Wage Profiles by Lifetime Income (LI) Group

\begin{tabular}{ll|l|l|l|l} 
LI Group & \multicolumn{1}{l|}{ Intercept } & \multicolumn{1}{l|}{ Age } & \multicolumn{1}{l|}{$\begin{array}{l}\text { Age- } \\
\text { Squared }\end{array}$} \\
\hline 1 & -0.6421 & 0.0949 & -0.0016 & $7 \mathrm{E}-06$ \\
2 & -0.2294 & 0.0941 & -0.0016 & $7 \mathrm{E}-06$ \\
3 & 0.1831 & 0.0929 & -0.0016 & $7 \mathrm{E}-06$ \\
4 & 0.4693 & 0.0907 & -0.0016 & $7 \mathrm{E}-06$ \\
5 & 0.6772 & 0.0882 & -0.0015 & $7 \mathrm{E}-06$ \\
6 & 0.8865 & 0.0853 & -0.0015 & $7 \mathrm{E}-06$ \\
7 & 0.9794 & 0.0884 & -0.0015 & $7 \mathrm{E}-06$ \\
8 & 1.1606 & 0.0864 & -0.0015 & $7 \mathrm{E}-06$ \\
9 & 1.3180 & 0.0855 & -0.0015 & $7 \mathrm{E}-06$ \\
10 & 1.4814 & 0.0862 & -0.0015 & $7 \mathrm{E}-06$ \\
11 & 1.8151 & 0.0856 & -0.0015 & $7 \mathrm{E}-06$ \\
12 & 2.5745 & 0.0853 & -0.0015 & $7 \mathrm{E}-06$
\end{tabular}

